\title{
Conventional agrochemicals towards nano-biopesticides: an overview on recent advances
}

\author{
Danial Abdollahdokht ${ }^{1}$, Yunhao Gao ${ }^{2}$, Sanaz Faramarz ${ }^{3}$, Alireza Poustforoosh ${ }^{4}$, Mojtaba Abbasi ${ }^{1}$, \\ Gholamreza Asadikaram ${ }^{1}$ and Mohammad Hadi Nematollahi ${ }^{5^{*}}$ (1)
}

\begin{abstract}
Pesticides are classified into several groups based on their structure, including fungicides, insecticides, herbicides, bactericides, and rodenticides. Pesticides are toxic to both humans and pests. For pest control, a very small amount of pesticides reach their target pests. Therefore, nearly all pesticides move through the environment and exert adverse effects on beneficial biota and public health. These chemicals pollute the water, soil, and atmosphere of the ecosystem. Agricultural workers in greenhouses and open fields, exterminators of house pests, and workers in the pesticide industry are occupationally exposed to pesticides. Pesticide exposure in the general population primarily happens through the consumption of food and water contaminated with pesticide residues; however, substantial exposure can also occur outside or inside the house. Currently, intelligent, responsive, biodegradable, and biocompatible materials have attracted considerable interest for the formulation of green, safe, and efficient pesticides. It was indicated that utilizing nanotechnology to design and prepare targeted pesticides with an environmentally responsive controlled release via chemical modifications and compounds offers great potential for creating new formulations. Furthermore, biopesticides include microbial pesticides, which are naturally happening biochemical pesticides. In addition, pesticidal substances generated by plants with added genetic materials, i.e., plant-incorporated protectants (PIPs), have emerged. Based on the foregoing evidence, various types of pesticides are summarized in this review for the first time. Here, new pesticides including nano-pesticides and biopesticides are discussed while focusing on the most recent findings on targeted and safe nano-formulated biopesticides and nano-pesticides.
\end{abstract}

Keywords: Pesticide delivery, Environment, Pollution, Targeted delivery, Nano-pesticide, Biopesticide

\footnotetext{
*Correspondence: mh.nematollahi@yahoo.com

${ }^{5} \mathrm{Herbal}$ and Traditional Medicines Research Center, School of Pharmacy,

Kerman University of Medical Sciences, Kerman, Iran

Full list of author information is available at the end of the article
} 


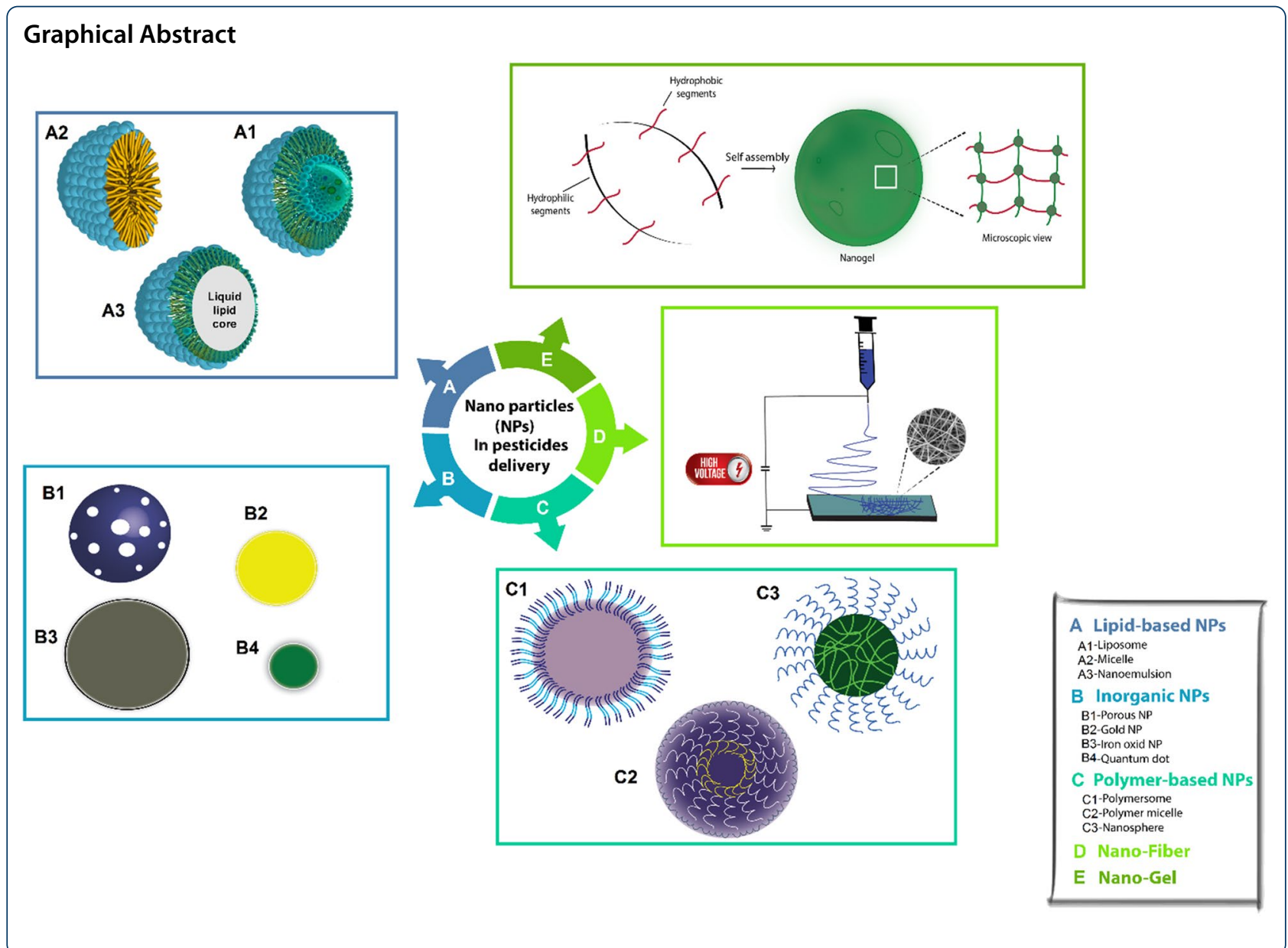

\section{Introduction}

Pesticides are chemicals that can be used to control pests and prevent plant diseases. Organophosphates, chlorinated hydrocarbons, carbamates, and carbamide derivatives are the most common active ingredients (AIs) in these substances [1]. These compounds are commonly used in veterinary medicine, agriculture, and health. They can harm humans and animals via skin absorption, inhalation, and dietary intake, as well as contaminating the environment [2]. Improper use of pesticides in agriculture leads to changes in the level of antioxidant and oxidant enzymes in the human body, and thus results in the development of diseases caused by oxidative stress [2-5].

Traditional pesticide formulations have a variety of limitations, including high organic solvent content, dust drift, low dispersibility, the ability to last in the soil for an extended period, and other similar drawbacks. Due to these limitations, the majority of pesticides are released into the air, with only $1 \%$ remaining on surfaces. This inefficiency leads to severe pollution of the environment. Therefore, pesticide waste, manufacturing costs, and environmental emissions should all be minimized in addition to extending the period in which pesticides are active on crops [6].

Some pest-control researchers are concentrating their efforts on creating non-toxic alternatives to synthetic chemicals for pest and disease control. One of these alternative methods is the use of biopesticides [7]. Biopesticides, also known as "biological pesticides", are used to control plant pests as an alternative for chemical pesticides [8-10]. The following are the key advantages of biopesticides as natural compounds over traditional pesticides: (i) lower toxicity; (ii) exclusively affecting the pest in question and closely related species; (iii) high potency in small doses; (iv) rapid decomposition; and (v) low exposition with almost no emission issues [11].

Another topic of debate regarding biopesticides is the use of nanotechnology, which has given new properties to old materials $[8,10,12-14]$. Nano-materials have significant applications in fields such as pharmacology 
and biology, because their physical and chemical properties differ from those of macro-materials. Nanomaterials are distinguished by their surface properties, small scale, and quantum size effects. The use of nanomaterials and the developments in pesticide formulations have increased significantly in recent years [13]. Nano-carrier materials also prevent AIs from degrading and allow for a controlled release [15].

\section{Pesticides}

\section{Types of pesticides}

The purpose of pesticide production is to remove pests and weeds. Farmers use pesticides to protect and enhance the quality of their crops [16]. As shown in Fig. 1, pesticides are divided into five groups based on their structure: fungicides, herbicides, insecticides, rodenticides, and bactericides [17].

\section{Fungicides}

Fungicides are pesticides that protect plants against fungal diseases by killing or incapacitating fungi. From
1940 to 1970, fungicides with new chemical structures were introduced (Fig. 2), including dithiocarbamates and phthalimides (organic chemicals), which were more active, less phytotoxic, and easier to prepare than the previously known inorganic fungicides. The fungicides mancozeb and chlorothalonil, known as protective fungicides, were also made during this period. Systemic methods as well as foliar and seed treatment were developed in this decade. Experiments were switched from in vitro to in vivo, and new products were tested in vivo [18].

Fungicides have evolved since the 1970s. During this period, more attention has been paid to the environment and human health, and in 1993, the European Union passed a law, according to which the produced fungicides had to be certified safe by the Union. A list of these fungicides is given in Fig. 3 [19].

During 2005-2021, attempts were made to produce fungicides that reduce the negative effects of artificial factors such as waste, resistance, and environmental pollution. In this regard, fungicides that was made may be selective effective, biodegradable, and less

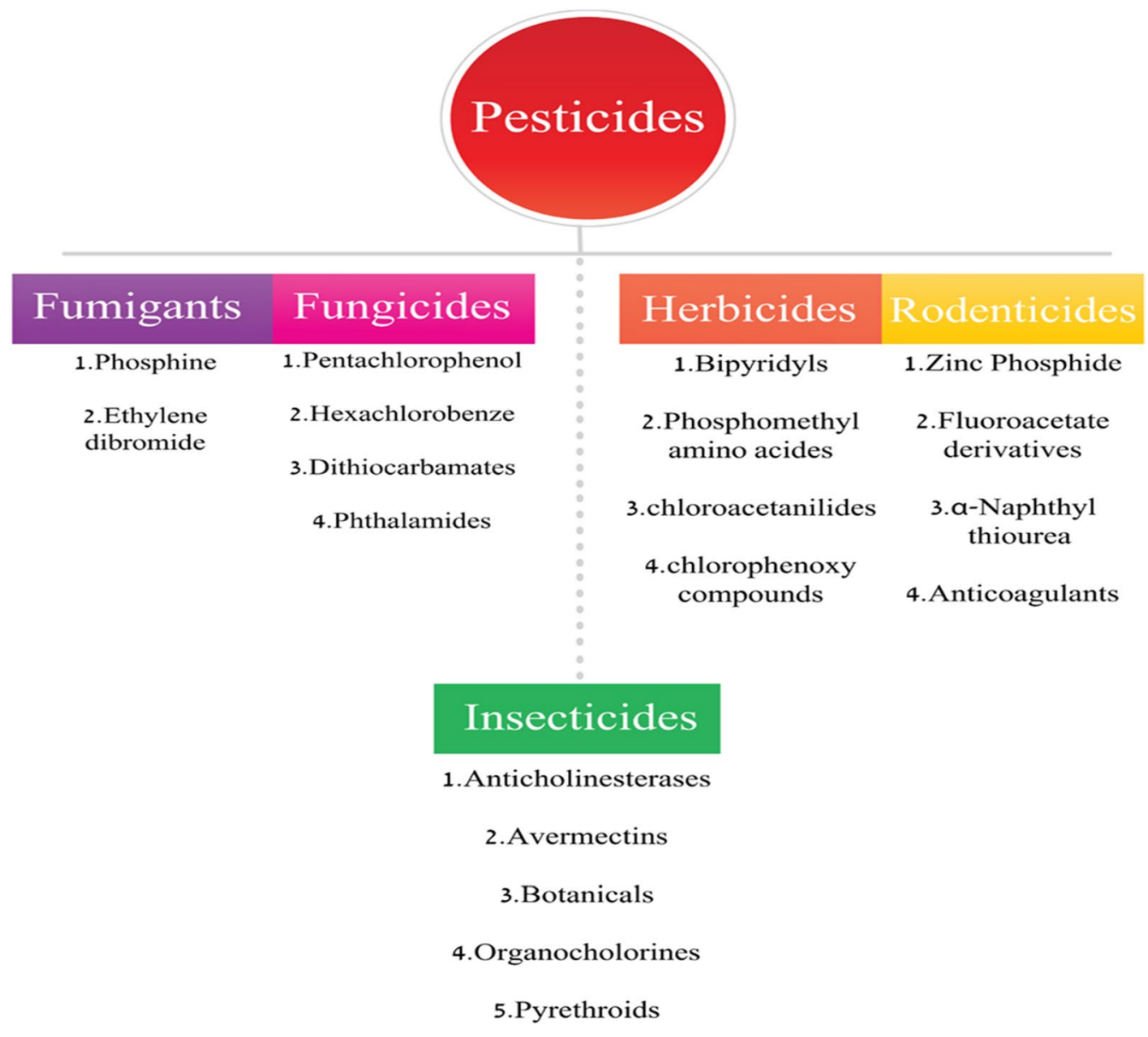

Fig. 1 General classification of pesticides based on target organism 


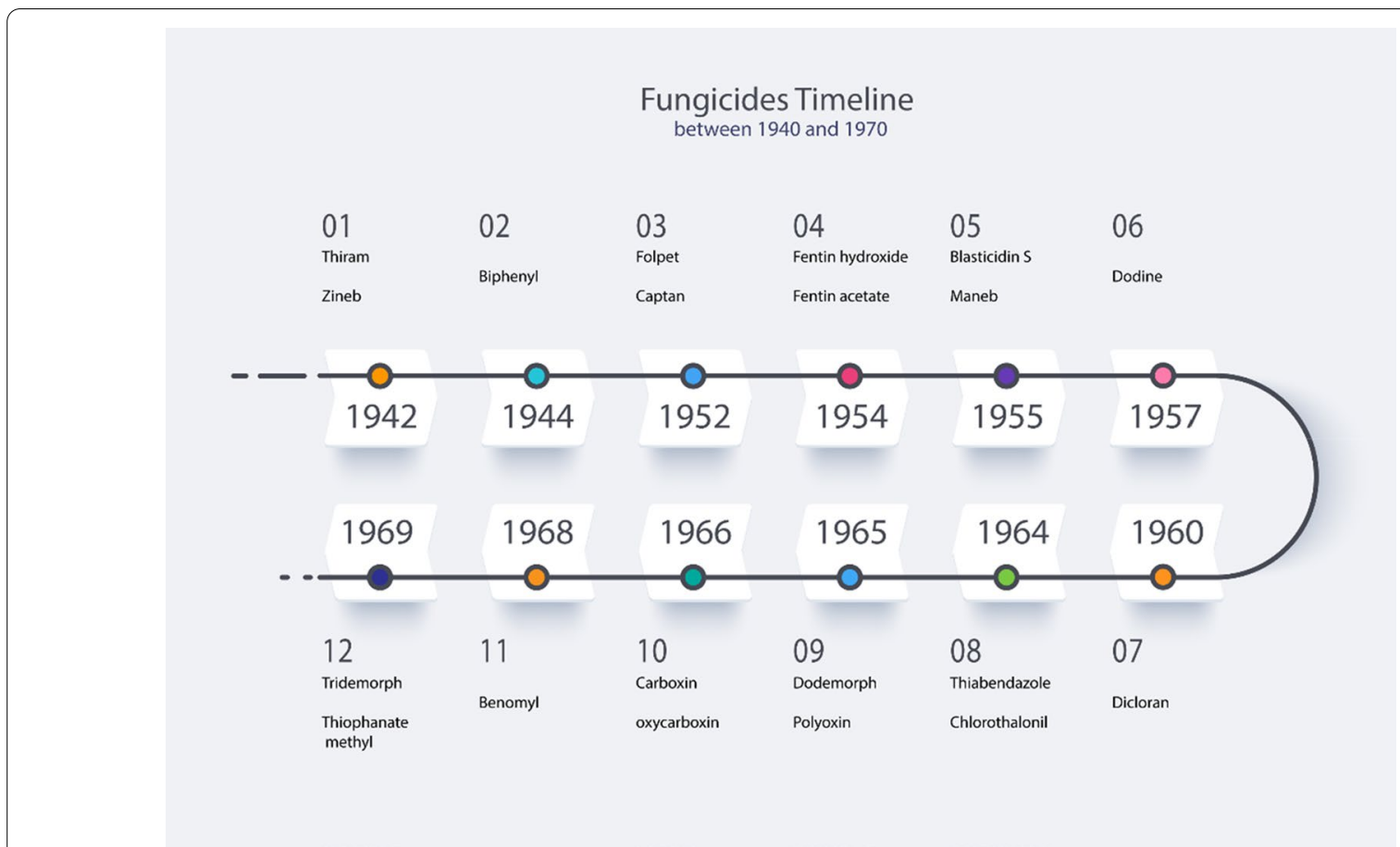

Fig. 2 Key classes of fungicides introduced between 1940 and 1970

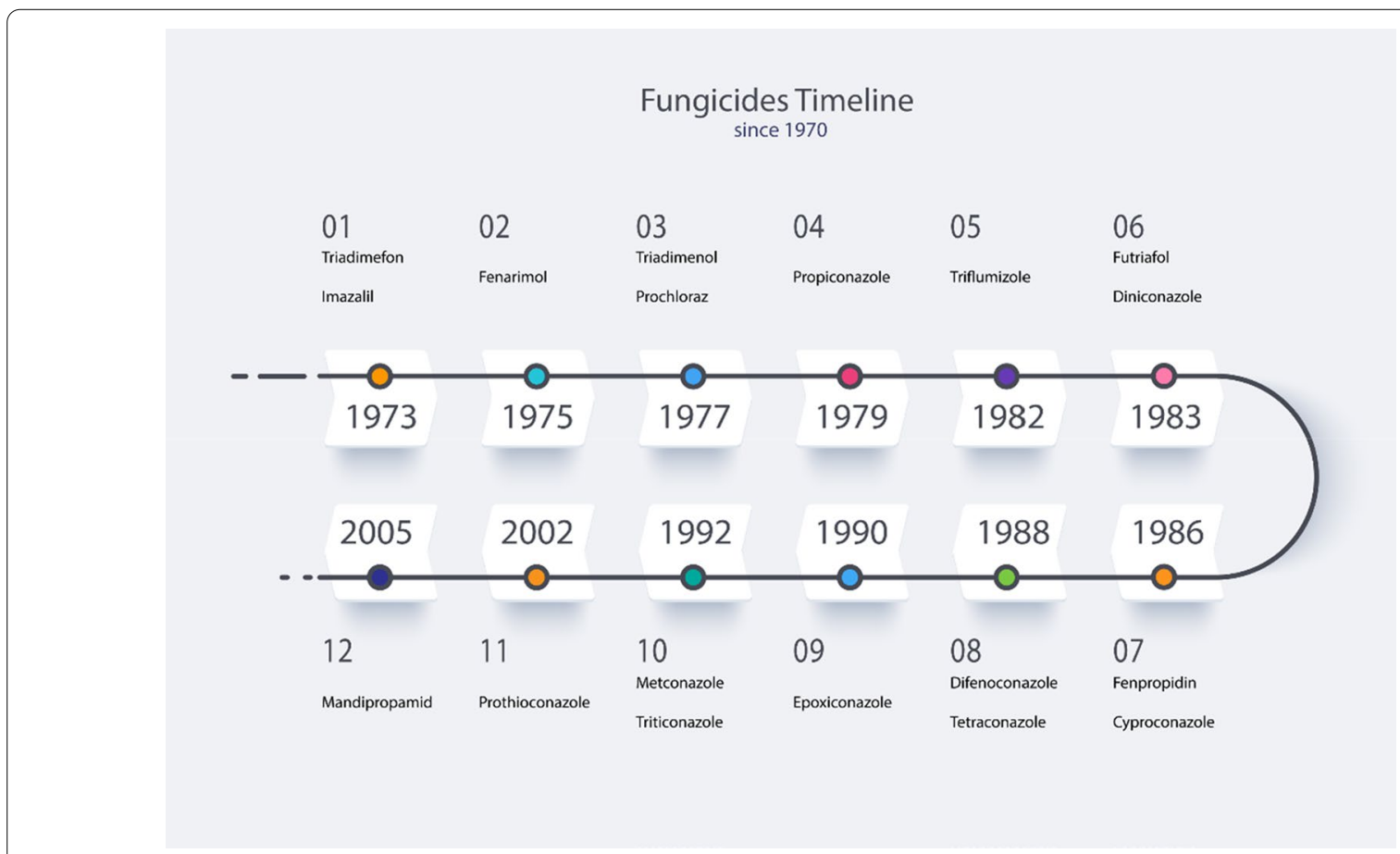

Fig. 3 Main fungicides introduced since 1970

environmentally toxic [20]. Several classes of fungicides introduced in this period. For instance, multi-site inorganic salts, organic compounds with protectant action, and single-site systemic fungicides with curative activity [21]. However, the latest discovery is succinate dehydrogenase inhibitor (SDHI) fungicides. SDHI are active 
components that used in fungicides to control certain fungi. SDHIs inhibit their growth by blocking the enzyme involved in cellular respiration [22]. In the next few years, biopesticides will probably completely replace current pesticides, because they are completely harmless to the environment and humans [23]. A list of these fungicides is given in Fig. 4.

\section{Herbicides}

Herbicides are used to eliminate weeds. A weed is a plant that interferes with the growth of crop plants and causes significant problems for farmers. In the early days when humans discovered agriculture $(10,000 \mathrm{BC})$, weeds were removed by hand. Over time, in about $6000 \mathrm{BC}$, primary hand tools were used to remove weeds. In $1000 \mathrm{BC}$, oxen and horses that pulled harrows were employed for this purpose. Since 1920, with the development of the agricultural industry, cultivators have been used, and in 1930 and 1947, biological and chemical herbicides were developed, respectively [24]. A mode of action is a functional or anatomical change that occurs when a living organism is exposed to a substance. According to some articles, the mode of action is limited to the cellular level. A mechanism of action, on the other hand, explains such changes at the molecular level [25]. Herbicides are divided into the following groups based on their mechanism of action:

Acetyl-coenzyme A carboxylase (ACCase) inhibitors These herbicides inhibit the activity of the enzyme ACCase and are used to control weeds during the culti- vation of broadleaf plants [26]. Aryloxyphenoxypropionates (FOP) [27], cyclohexanedione (DIM) [28], and phenyl pyrazoline (DEN) are a few examples of these herbicides [29].

Acetolactate synthase (ALS) inhibitors ALS is an enzyme that is involved in the synthesis of branched-chain amino acids (leucine, isoleucine, and valine) and the suppression of this enzyme causes the plant to wither and eventually die [26].

Root growth inhibitors These herbicides inhibit cell division, thus preventing root growth and development. The purpose of these herbicides is to block the polymerization of microtubules, which disrupts the process of chromosome segregation during mitotic division, resulting in cell death [26].

Plant growth regulators This group includes hormonal herbicides (synthetic auxins), which are used to protect wheat and corn against broadleaf grasses. This group of herbicides targets the ATP protein pump. By activating this pump, the metabolism of nucleic acids and the integrity of the cell wall are compromised. These herbicides are also called indole acetic acid (IAA) imitators [26].

Photosynthesis/photosystem II (PSI) inhibitors The target of these herbicides is the photosynthetic pathways (especially the photosystem II pathway). As a result of the loss of chlorophyll and other pigments such as carotenoids

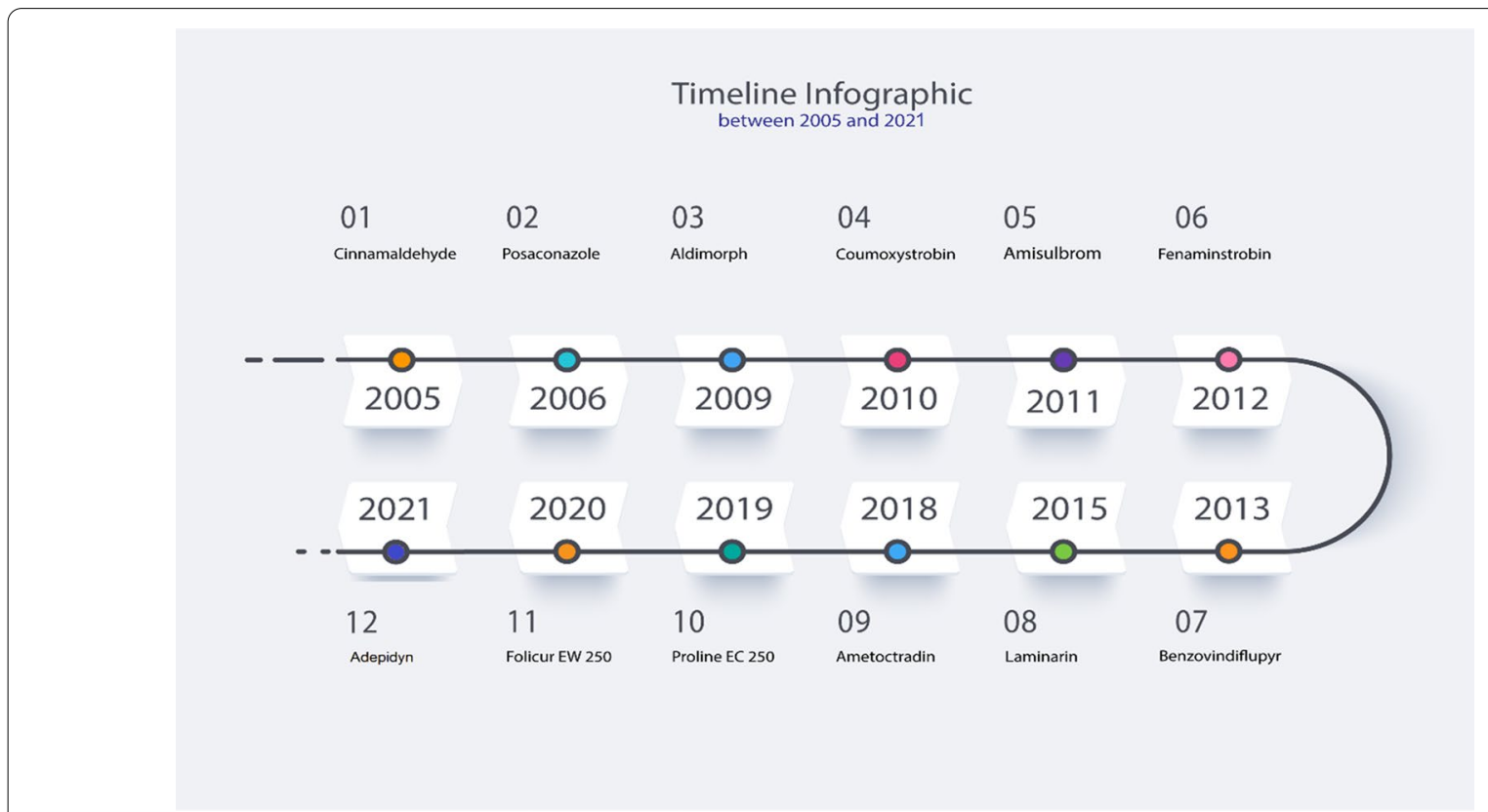

Fig. 4 Main fungicides introduced between 2005 and 2021 
from the cell membrane, the production of $\mathrm{NADPH}_{2}$ and ATP, which are essential for plant growth, is disrupted, eventually leading to plant death [26].

Shoot-growth inhibitors These herbicides are applied to the soil prior to the emergence of the weeds. The functional site of these herbicides is on very long-chain fatty acids (VLCFA) [26].

Aromatic amino acid inhibitors This group of herbicides inhibits the synthesis of amino acids. This action is specific to glyphosate. These herbicides destroy any plant they come in contact with, although they are only licensed for corn, cotton, canola, and soybeans. Glyphosate inhibits the enzyme essential for the production of 5-enolpyruvylshikimate 3-phosphate (EPSP), resulting in a decrease in aromatic amino acids, i.e., tryptophan, tyrosine, and phenylalanine, and eventually cell death [26].

Glutamine synthetase inhibitors These herbicides suppress the activity of glutamine synthetase, which is involved in the conversion of glutamate and ammonia to glutamine, thus increasing the level of ammonia and lowering $\mathrm{pH}$ on both sides of the cell membrane. This activity disrupts various cellular functions, especially the uncoupling of photophosphorylation [26]. One example of these herbicides is glufosinate [30].

Pigment synthesis inhibitors These herbicides destroy chlorophyll, which is essential for photosynthesis in plants. As a result, they cause the plant tissues to turn white, which eventually causes the weeds to die [26]. Some examples include isoxazolidinone and isoxazole [31].

Protoporphyrinogen oxidase (PPO) inhibitors These herbicides damage cell membranes by inhibiting the enzyme PPO. This enzyme is implicated in chlorophyll and heme biosynthesis. Lipid peroxidation occurs following the inhibition of this enzyme, which destroys cell membranes and leads to plant death [26].

\section{Insecticides}

Insecticides are substances used to kill insects and are widely used in medicine, agriculture, and industry. Before 1900, only a few chemicals were used as pesticides; however, in the early 1940s, as the Second World War raged on, the insecticide DDT was produced. These insecticides were game-changers. Since then, farmers have been using an ever-expanding list of insecticides to protect their crops. Their use has undoubtedly resulted in substantial increases in agricultural output and a decrease in disease transmission, but it has also resulted in major challenges, including health concerns for pesticide consumers and the general public, the rise of pesticide resistance, and environmental issues [32].

Insecticides mainly attack three targets in the nervous system: acetylcholinesterase, which is a vital enzyme in nerve impulse transmission (organophosphates and carbamates), voltage-gated sodium channels through the nerve membrane (pyrethroids and DDT), and the acetylcholine receptor (neonicotinoids) [33]. Selective insecticides, such as juvenile hormone mimics (fenoxycarb and pyriproxyfen) [34], ecdysone agonists, and chitin synthesis inhibitors (diflubenzuron), impede insect reproduction and growth by acting on insect-specific targets [35]. Azadirachtin, a feeding deterrent and insect growth regulator, derived from the Indian neem tree, suppresses fecundity, pupation, molting, and adult emergence [36]. Modern insecticides used in pest control include imidacloprid, acetamiprid, and thiamethoxam, which selectively act on the insect's nicotinic acetylcholine receptor (neonicotinoids) [37]. Avermectins are microbial insecticides that target GABA-gated chloride channels, while the ryanodine receptor is targeted by diamide insecticides [38]. Spinosyns are a new generation of insecticides derived from actinomycetes, which exhibit high specificity and low mammalian toxicity while also being environmentally friendly [39].

\section{The destructive effects of pesticides on humans and the environment}

Pesticides have negative effects on both human health and the environment [40]. Pesticide poisoning causes around 1 million deaths and chronic diseases worldwide per year [41]. Production workers, formulators, sprayers, mixers, loaders, and agricultural field workers are among the high-risk groups exposed to pesticides. Pesticide compounds can pollute tissues of nearly any living organism on the planet, as well as air, oceans, the fish that live in the oceans, and even the birds that consume the fish [42]. Some pesticides have negative health effects through mimicking or antagonizing natural hormones in the body, and it has been suggested that long-term, lowdose exposure is progressively linked to hormone disruption, immune suppression, reduced intelligence, cancer, and reproductive defects [43]. Some pesticides (carbamates, organophosphates, organochlorines, and pyrethroids) also have neurological effects and are linked to diseases such as Alzheimer's and Parkinson's [44].

\section{Safe target delivery of pesticides}

In recent years, the limitations of conventional pesticide formulations have prompted new research focusing on carefully controlled release. On farmlands, controlled pesticide release systems are used to specifically control a target pest by choosing a suitable and applicable output 
path. Using a smart design that delays and monitors pesticide release, this strategy aims to reduce the demand for pesticides in crops, allowing for more efficient pesticide application over time [45].

\section{New pesticides}

According to the World Health Organization (WHO), pesticides are a major threat to the environment and humans [46]. For this reason, new pesticides with novel natural and synthetic components are developed, which are less toxic, specific to a target pest, effective in small quantities, and decompose more quickly than conventional pesticides [47]. New pesticides are divided into two categories: biopesticides and nano-pesticides.

\section{Biopesticides}

Biopesticides are pest-control agents made from microorganisms, plants, and animals. Synthetic pesticides continue to strongly protect agricultural products, but their long-term use has negative effects such as carcinogenicity, long-term stability in the environment, and other similar consequences. To address these issues, the production of new pesticides became necessary [48]. Biopesticides were considered, since they are safe and eco-friendly.

Fungal spores were first used as a biopesticide in the late 1800s to control insect pests. In 1835, Agostine Bassi demonstrated that spores of the white muscardine fungus (Beauveria bassiana) could protect silkworms from diseases. This was one of the first documented cases of biopesticide use. Since then, the application of biopesticides has been continuous throughout modern agricultural history, although it has remained minimal compared to conventional crop protection. The primary distinction between biopesticides and synthetic pesticides is their mode of action. While most synthetic insecticides, if not all, are neurotoxic to pests, many biopesticides have other modes of action, such as anti-feeding, mating disturbance, desiccation, and suffocation. Biochemi$\mathrm{cal}$, microbial, and plant-incorporated protectants (PIPs) are the three types of biopesticides identified by the US Environmental Protection Agency (EPA) (Fig. 5). Recent reports of the various properties of biopesticides are presented in Table 1 [49].

\section{Microbial pesticides}

Microorganisms such as viruses, bacteria, fungi, protozoa, and yeasts are used to produce biopesticides. Microbial pesticides are a more effective alternative to chemical insecticides. Their pathogenicity to the target pest varies depending on the species [67]. The effect of microbial pathogens is induced by the invasion of the pathogen through the skin or the gut of the insect, which results in pathogen multiplication and the death of the host, i.e., the insect. Insecticidal toxins produced by pathogens are critical in their pathogenesis. The majority of toxins produced by microbial pathogens are recognized as peptides, but their structure and toxicity vary considerably.

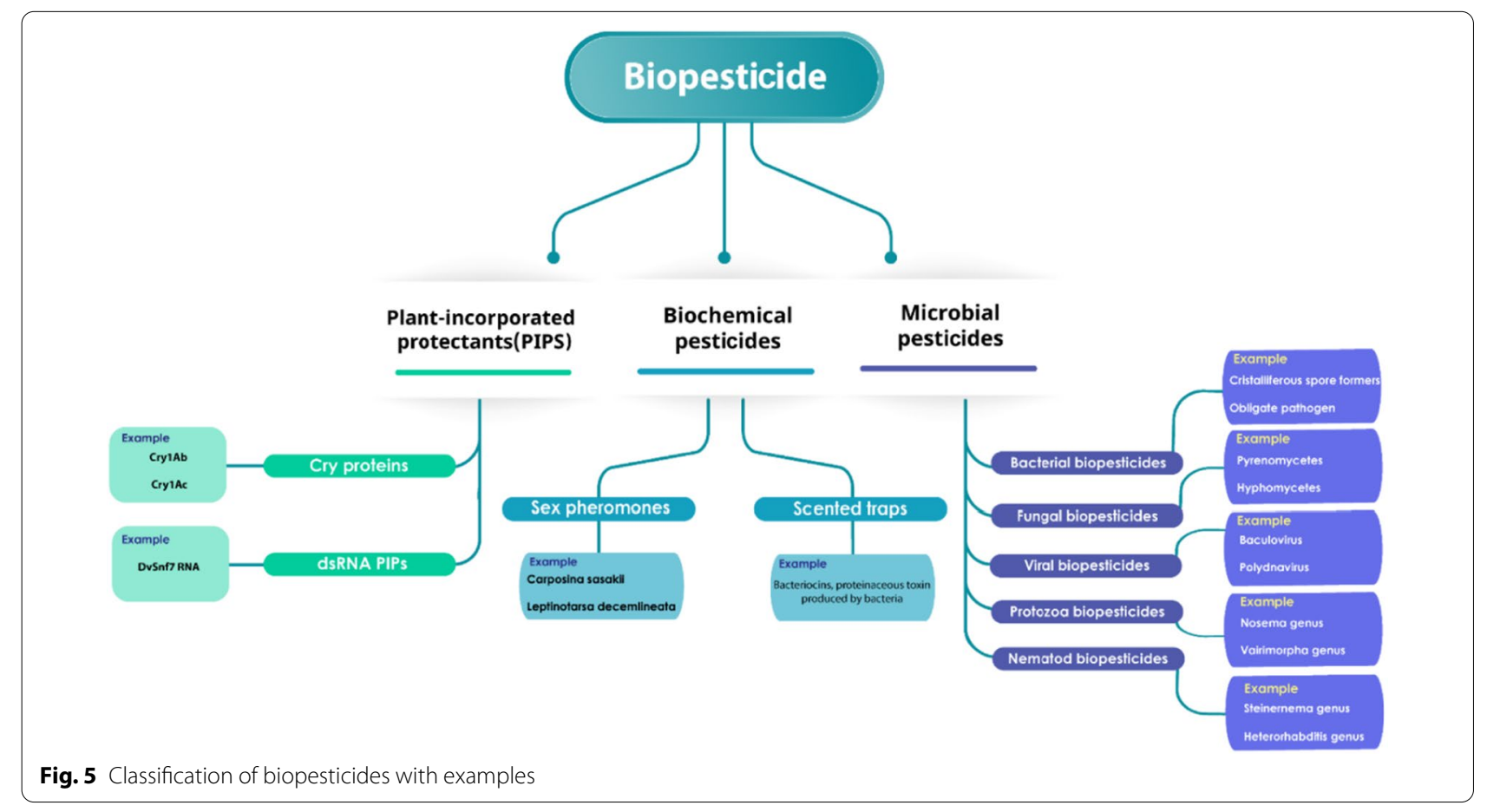


Table 1 Recent reports of various substances with biopesticide properties

\begin{tabular}{|c|c|c|c|}
\hline Biopesticide & Target pest & Action & References \\
\hline Oxathiapiprolin & Plasmopara obducens & Fungicide & {$[50]$} \\
\hline Beauveria bassiana & Arthropod pests & Fungicide & [51] \\
\hline Alternaria destruens & L. sinense & Herbicide & [52] \\
\hline Myrothecium vaerrcaria & Ticks & Insecticide & [53] \\
\hline Heterorhabditis bacteriophora & Otiorhynchus sulcatus & Insecticide & [54] \\
\hline Heterorhabdits species & Helicoverpa armigera & Insecticide & {$[55]$} \\
\hline Micro-encapsulated baculoviruses & Insect crop pests & Insecticide & {$[56]$} \\
\hline $\begin{array}{l}\text { Hydrolate derived from } \\
\text { A. absinthium }\end{array}$ & Meloidogyne javanica & Nematicide & {$[57]$} \\
\hline Biopesticide methionine & Honey bees & Insecticide & [58] \\
\hline Spider venom neurotoxin & Hive beetle & Insecticide & [59] \\
\hline Cordycepin & C. militaris & Fungicide & {$[60]$} \\
\hline Crucifalexins & Fungi & Fungicide & {$[61]$} \\
\hline Chromobacterium sp. Panama & Larval mosquito & Insecticide & {$[62]$} \\
\hline B. pumilus chitinase & $\begin{array}{l}\text { R. solani } \\
\text { T. harzianum }\end{array}$ & Fungicide & [63] \\
\hline Triflumezopyrim & Rice planthoppers & Insecticide & [64] \\
\hline SK gene & Tribolium castaneum & Insecticide & {$[65]$} \\
\hline D-limonene & Fungi & Fungicide & {$[66]$} \\
\hline
\end{tabular}

Humans and other non-target species can benefit from the effectiveness and safety of the pesticides. These pathogens leave their meals with little or no residues [68]. Microbial pesticides are ecologically safe and remove threats from other natural pests, resulting in increased biodiversity in managed ecosystems. As a result, microbial agents are highly specific against target pests, allowing beneficial insects to thrive in treated crops. This is the reason why, over the last 3 decades [69], microbial insecticides have been introduced as biological control agents. Different pests can be controlled using different microorganisms as the AIs, such as bacteria, fungi, viruses, or protozoa; however, each active ingredient is relatively specific for its target pest. Some fungi, for example, control certain weeds, while others kill particular insects. As another example, Bacillus thuringiensis toxin may be more effective against Aedes aegypti, while the sphaericus strain is effective against a variety of insects, including Culex quinquefasciatus [70].

\section{Biochemical pesticides}

Biochemical pesticides are substances naturally occurring in the environment, which control pests via a non-toxic mechanism. The mechanism of action of biochemical pesticides is different from that of traditional pesticides. Traditional pesticides directly affect and destroy their target, but biochemical pesticides act indirectly. For example, they disrupt the sexual function of their targets. Natural plant-derived products such as terpenoids, alkaloids, phenolics, and other secondary chemicals may be used as biopesticides. Pesticidal properties have also been discovered in certain vegetable oils, such as canola oil [71].

\section{PIPs}

PIPs are pest-control substances made by plants and the genetic material needed for the plant to make the substance [72]. The majority of pesticides in use are synthetic organic compounds with low molecular weights (LMWs, less than $500 \mathrm{~g} / \mathrm{mol}$ or $0.5 \mathrm{kDa}$ ). These pesticides' environmental and analytical chemistry, as well as their potential effect on human and environmental health, have been thoroughly investigated. While LMW-synthetic pesticides have dominated the market, biopesticides are becoming an increasingly important part of the overall pesticide market [73]. The global market for all biopesticides is currently estimated to be worth $\$ 34$ billion, accounting for approximately $6 \%$ of the total pesticide market. PIPs are biopesticides that are expressed directly in the tissue of genetically modified (GM) crops to protect them from pests such as insects and viruses. Because of the widespread use of insecticidal PIPs around the world, as well as the recent emergence of new PIPs targeting insect pests, this section focuses on PIPs developed against insects [74]. Insect pests consume PIPs when feeding on the transgenic crop tissue. Cry protein and double-stranded ribonucleic acid (dsRNA) PIPs in the insect gut affect 
insect development or cause insect mortality in various ways [75]. Cry protein PIPs interact with specific receptors on epithelial cells in the insect midgut, insert into the cell membrane, and eventually form transmembrane pores, which lead to cell lysis and pest death. There are several types of Cry proteins, each with a specific structure and toxicity that is unique to certain insect orders. Lepidoptera (e.g., the corn borer) is poisoned by Cry1 proteins, while Coleoptera (e.g., the corn rootworm) is poisoned by Cry3 proteins.

Cry proteins were the first-generation insecticidal PIPs. The next-generation dsRNA PIPs have been recently approved. Following ingestion, the dsRNA PIPs in the pest insect are transported into a target cell. dsRNA is cleaved into small interfering RNA molecules (siRNA, 20 nucleotides) within the cell, which guides the insect's endogenous RNA interference (RNAi) machinery to degrade the complementary mRNA. The degradation of the targeted mRNA prevents it from being translated into basic pest insect proteins, causing sublethal effects (e.g., decreased growth) or pest mortality (Fig. 6). The first dsRNA PIP to be approved by the FDA targets the corn rootworm (Diabrotica virgifera virgifera) by interfering with the synthesis of the Snf7 protein, which is an important vacuolar sorting protein [76].

\section{Nano-pesticides}

Engineered nanoparticles are now being used, or have the potential to be applied, as novel carriers for pesticide delivery. A range of formulation types has been suggested, including nano-emulsions, nano-encapsulations, nano-vesicles, nano-gels, nano-fibers, etc., which can be used to improve the efficacy of existing pesticide AIs or to enhance their environmental safety profiles, or both [77]. The most common nanoparticles are illustrated in Fig. 7.

\section{Nano-emulsion}

Nano-emulsion is a biphasic dispersion system formed by mixing surfactants; AIs dissolved in the oil phase and the water phase [78]. The nanometer-sized droplets ( 20-200 nm) make this system kinetically stable and give it a transparent or translucent appearance $[79,80]$. Nano-emulsion of pesticides is an oil-in-water $(\mathrm{O} / \mathrm{W})$ dispersion, which can dissolve poorly water-soluble pesticides into small oil droplets and greatly improve their bioavailability and efficacy [81, 82]. In addition, nanoemulsion significantly reduces the use of organic solvents and surfactants compared to traditional pesticide formulations, and has attracted considerable attention from researchers in recent years [83, 84]. For example, Jiang et al. presented a nano-emulsion system that

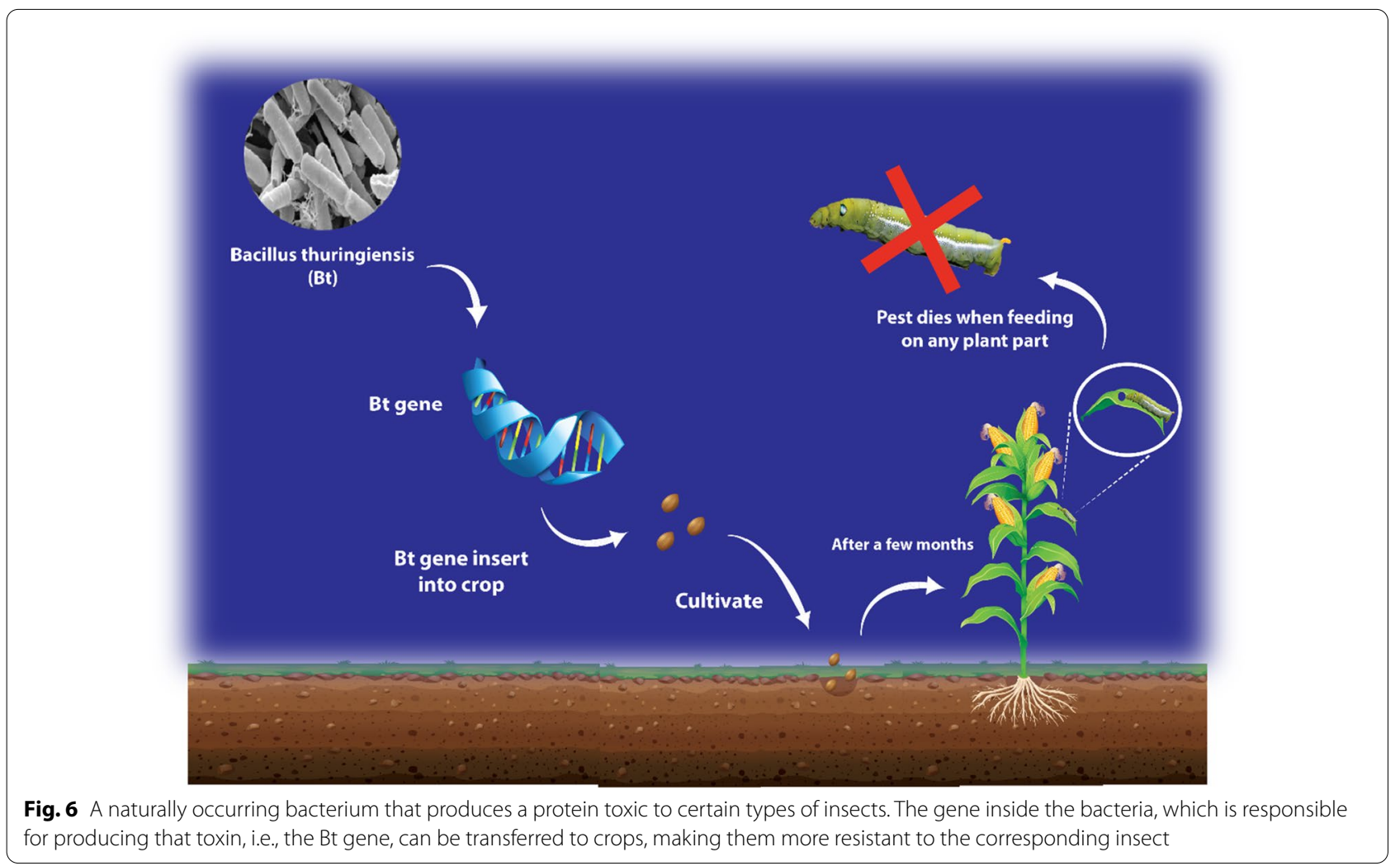




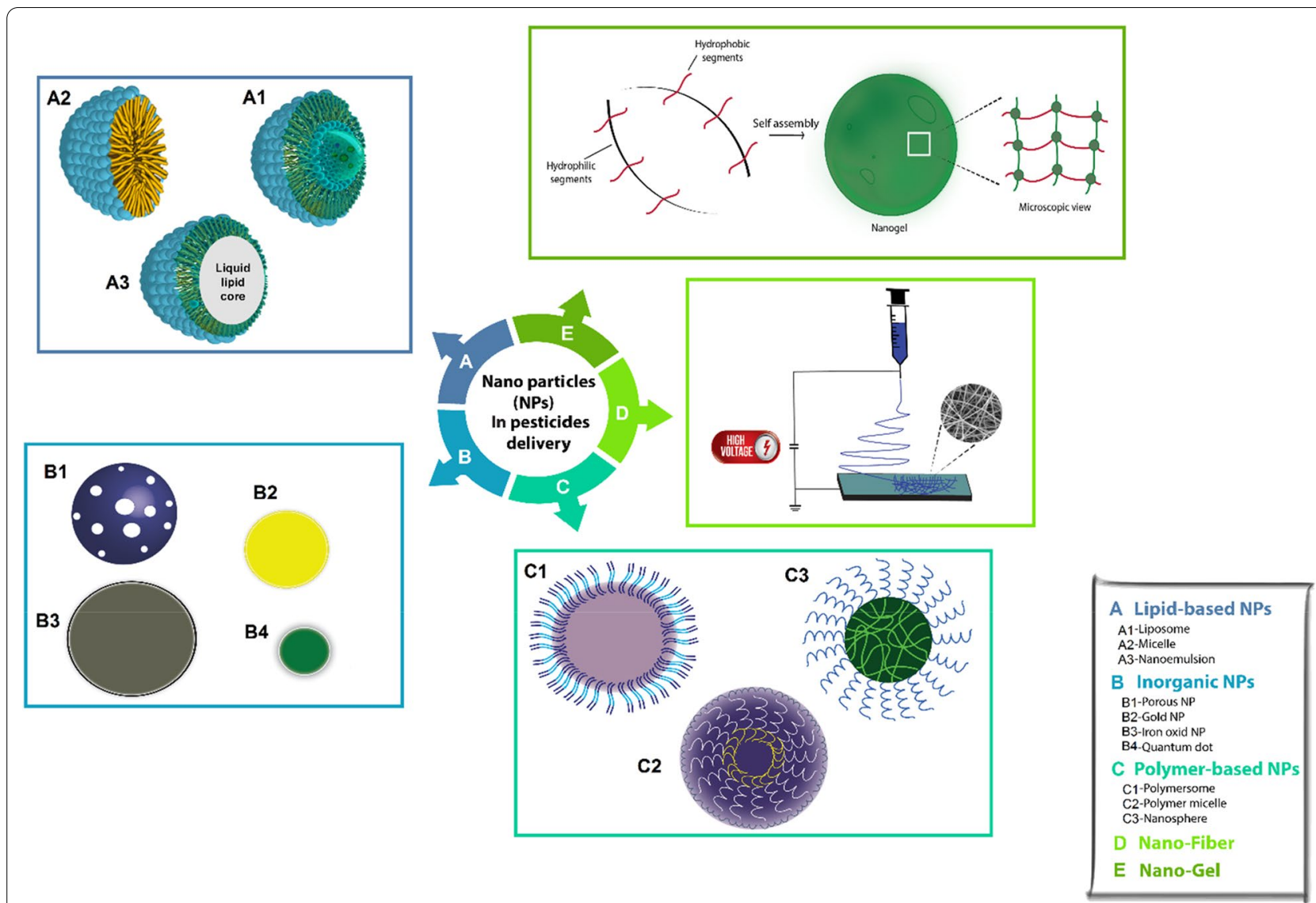

Fig. 7 Nanoparticles in pesticide delivery: A Lipid-based nanoparticles. B Inorganic nanoparticles. C Polymer-based nanoparticles. D Nanofibers. E Nano-gels

encompassed environmentally friendly surfactants, esterified vegetable oils, and $41 \%(\mathrm{w} / \mathrm{w})$ herbicide glyphosate isopropylamine [85]. This nano-emulsion had a small particle size $(<200 \mathrm{~nm})$ and lower surface tension than the commercial cationic surfactant system (Roundup ${ }^{\circledR}$ ), which would cause the droplets to be deposited uniformly on leaves with lower contact angle and increase the wetting, spreading, and permeation. Visual injury assessment indicated that the nano-emulsion formulations showed significantly lower effective dose $50\left(\mathrm{ED}_{50}\right)$ than Roundup ${ }^{\circledR}$, suggesting that they exhibited higher biological efficacy. In another study, Feng et al. developed an abamectin (Abm)-loaded nano-emulsion containing 2\% Abm, 5\% castor oil polyoxyethylene, and 7.5\% hydrocarbon solvent, which conformed to the quality indicators of the Food and Agriculture Organization (FAO) [86]. Compared with commercial oil/water emulsions (EW) and microemulsions (ME), the nano-emulsion exhibited various advantages such as a smaller dynamic contact angle on cabbage leaves, higher insecticidal activity, and lower cytotoxicity. Although a nano-emulsion of pesticides with remarkable physical stability can be readily obtained, the most common approach is high-energy emulsification, and the oil phase and emulsifiers may still be toxic [87, 88]. To overcome these challenges, green nano-emulsions and low-energy methods (e.g., self-emulsification, phase transition, phase inversion temperature methods, etc.) are promising strategies $[89,90]$. Du et al. developed a green nano-emulsion of $\beta$-cypermethrin using renewable fatty acid methyl ester (methyl laurate) as the oil phase, "green surfactant" alkyl polyglycoside, and the non-ionic surfactant polyoxyethylene 3-lauryl ether $\left(\mathrm{C}_{12} \mathrm{E}_{3}\right)$ as the mixed surfactant [89]. The nano-emulsion incorporating $\beta$-cypermethrin had a nearly monodisperse droplet size distribution (polydispersity index (PDI) $<0.2 \mathrm{Mw} / \mathrm{Mn}$ ), which indicated excellent wetting and spreading properties on the hydrophobic surface compared with the commercial $\beta$-cypermethrin nano-emulsions, suggesting a biocompatible strategy for pesticide delivery.

\section{Nano-encapsulation}

Nano-encapsulation of pesticides is a delivery method in which AIs are encapsulated in various nanomaterials and released in a controlled way [91]. Encapsulation by 
nanomaterials can protect AIs from premature degradation (e.g., photolysis, hydrolysis, biodegradation, etc.) and unnecessary losses by leaching and volatilization, and it is more effective in practical applications than traditional pesticide formulations [92, 93]. After the rational design, nanomaterials can also enable the encapsulation system to exhibit sustained release behavior to prolong the control period or give it stimulus-responsive release properties to achieve precision control [94-96].

Various nanomaterials including organic materials (e.g., synthetic and natural polymers [97-102], lipids [103, 104], plant-derived nanoparticles [105-107], etc.), and inorganic materials (e.g., silica-, carbon-, calcium-, and clay-based nanoparticles, etc.) have been applied for nano-encapsulation of pesticides [95, 108]. AIs are often encapsulated into nanocarriers via incorporation, electrostatic complexation interactions, or covalent bonding, which will improve uptake, dispersibility, mobility, adhesion, and controlled or target release, thus leading to increased bioavailability and a longer effective lifetime of AIs. Due to their excellent biocompatibility and biodegradability, as well as their abundant functional groups, various forms of polymer-based nano-encapsulated pesticides, including nano-capsules, nano-spheres, nano-micelles, nano-gels, and nano-fibers, have been extensively investigated [100]. Lipid-based nano-encapsulation of pesticides not only can lead to effective encapsulation of hydrophobic or hydrophilic AIs without the need to use organic solvents but also can enhance their penetration and absorption in insect epidermis, resulting in an increased insecticidal activity. More recently, several published articles have demonstrated that the nano-encapsulation of the pesticides based on plant viral nanoparticles (red clover necrotic mosaic virus, tobacco mild green mosaic virus) could increase the mobility or distribution of Abm, a nematicide, within the soil compared to the free Abm, leading to enhanced crop protection against plant-parasitic nematodes in the soil [106]. Although nano-encapsulation of pesticides based on lowcost organic materials has been widely investigated, many challenges still need to be addressed, such as physicochemical instability and acid monomers formed by polymer degradation leading to the decomposition of AIs. Deteriorative reactions occur when polymers are subjected to heat, oxygen, and mechanical stress, and during the useful life of the materials when oxygen and sunlight are the most important degradative agencies. Moreover, degradation may be induced by high-energy radiation, ozone, atmospheric pollutants, mechanical stress, biological action, hydrolysis, and many other influences [109].

Porous inorganic materials such as silica and calcium carbonate are ideal carriers for pesticides because of their large surface area, tunable pore size, high loading capacity, and good biocompatibility [110-116]. The controlled release properties and anti-photolysis ability of AIs are significantly enhanced after encapsulation in those materials. Some articles have reported that the release behavior of encapsulated AIs could be regulated through controlling the pore structures (e.g., 2D hexagonal channel, 3D open network structure, single large pore, etc.), thus further improving the efficacy in practice $[117,118]$. In addition, some inorganic materials with specific shapes or structures have been reported for controlling the encapsulated AI loss. For example, the Wu group reported a high-energy electron beam (HEEB)-modified natural nano-clay that could effectively encapsulate chlorpyrifos and increase its adhesion on crop leaves through the 3D network structure [119]. In another study, Sharma et al. used graphene oxide decorated with copper selenide nanoparticles for the encapsulation of chlorpyrifos, which led to enhanced adhesion to cauliflower leaf due to the resistance of graphene oxide to aqueous runoff, the ability of carbon to bind to the organic surface, and the piercing effect by a sharp sheet on the plant leaf [120].

In general, nano-encapsulated pesticides have two typical release behaviors: (i) sustained (slow) release and (ii) stimuli-responsive release. For the sustained release of nano-encapsulated pesticides, AI concentrations remain within an effective control window against pests for a long period, avoiding frequent pesticide application. To achieve optimal control efficacy, developing stimuliresponsive nano-encapsulated pesticides that can precisely deliver AIs to the target is crucial. So far, various stimuli-responsive (e.g., pH-, enzyme-, temperature-, redox-, light-, ionic strength-, and humidity-responsive) nano-encapsulated pesticides have been reported for promoting the smart release of AIs in response to biotic (plant pathogens, insects, and weeds) or abiotic (temperature, sunlight, drought, soil texture, flooding, and salinity) stimuli, and have been discussed in detail in the previous reviews [94, 121-126]. These controlled release properties indicate the potential of nano-encapsulated pesticides for improving pesticide-use efficiency.

Vesicles such as liposomes and niosomes are versatile drug vehicles that are composed of various phospholipids or non-ionic surfactants [127, 128]. In general, they could carry both lipophilic and hydrophilic drugs anchored into their bilayer or encapsulated in their cavity, respectively. These vesicles have the potential to be used as carriers for pesticide delivery. Some studies have utilized vesicles for pesticide delivery. Kang et al. examined the impact of the nanoform of pyrifluquinazon on the destruction of the green peach aphid, Myzus persicae. The nanotype of pyrifluquinazon was constructed using liposomes and was subsequently covered with chitosan to make the unstable 
core materials more durable [129]. Moreover, to decrease the toxicity of paraquat, which is a widely used herbicide, photo-responsive and user-friendly vesicles loaded with paraquat were utilized. In this formulation, paraquat could only be released upon UV or sunlight irradiation [130]. Zhang et al. used liposomes to deliver the dsRNA of the P0 gene to the tick Rhipicephalus haemaphysaloides and evaluate the anti-tick characteristics of this system. Their findings revealed that P0 dsRNAs are virtually silenced [131]. Some of the studies that focused on nucleic acid delivery using vesicles in the context of crop protection are presented in Table 2.

\section{Nanoparticles}

Nanoparticle-based pesticides discussed herein mainly include two types, nanoparticles directly used as pesticides and pesticide nanoparticles. Organic/inorganic nanoparticles are widely investigated as pesticides for the management of insect pests and bacterial and fungal diseases of plants [140]. For example, some articles have reported the insecticidal activity of silica nanoparticles, nickel nanoparticles, and titanium dioxide nanoparticles against weevils (Sitophilus oryzae), cattle tick (Rhipicephalus microplus, Hyalomma anatolicum anatolicum), mosquito (Anopheles subpictus, Culex quinquefasciatus, and Culex gelidu), and Haemaphysalis bispinosa [141143]. Many metalloids (e.g., gold, silver, copper, platinum, etc.) and metal oxides (e.g., silver oxide, zinc oxide, copper oxide, titanium dioxide, etc.) [144-146], as well as nonmetal nanoparticles (e.g., sulfur [147, 148], reduced graphene oxide [149], and chitosan [150, 151], etc.), can be directly used as nano-pesticides owing to their antifungal or antibacterial activity.

In recent years, the use of bottom-up or topdown nanotechnology to formulate pesticide AIs as nanocrystalline particles has shown significant promise

Table 2 Nano-vesicles employed for the delivery of nucleic acids (dsRNA) in the context of crop protection

\begin{tabular}{lll}
\hline Nano-vesicle composition & Target species & References \\
\hline Lipofectamine & Euschistus heros & {$[132]$} \\
Lipofectamine & Spodoptera frugiperda & {$[133]$} \\
GenJe plus & Blattella germanica & {$[134]$} \\
Lipofectamine & Drosophila suzukii & {$[135]$} \\
Lipofectamine (Cellfectin, & Drosophila melanogaster, & {$[136]$} \\
DMRIE-C, Transfectin also & Drosophila sechellia, & \\
used in one assay) & Drosophila yakuba, & \\
& Drosophila pseudoobscura & \\
Cellfectin & Spodoptera frugiperda Sf9 & {$[137]$} \\
& cell line & \\
Effectene (Qiagen) & Aedes aegypti & {$[138]$} \\
Effectene (Qiagen) & Aedes aegypti & {$[139]$} \\
\hline
\end{tabular}

for improving the solubility and dispersion of poorly water-soluble pesticides [93]. After nanosizing pesticides, their solubility, permeability, dispersion, penetration, and bioactivity could be greatly improved [152]. Compared with commercial emulsions in water, nanosuspensions showed increased retention on leaf surfaces, improved anti-photolysis, and enhanced bioavailability. In a study by Wang et al., a pyraclostrobin solid nanodispersion with a mean particle size of $20 \mathrm{~nm}$ and zeta potential of $-29.3 \mathrm{mV}$ was prepared via the self-emulsifying method which exhibited superior wettability, retention, and storage stability [153]. As a result, the solid nanodispersion showed a greater than fourfold increase in fungicidal activity compared to the conventional water dispersible granule. Owing to their ease of large-scale production and wide applicability for almost all poorly water-soluble pesticides, the use of pesticide nanoparticles is emerging as the key innovative strategy for reducing pesticide consumption.

\section{Nano-gels}

Nano-gels have gained considerable interest from researchers as nanoscopic drug carriers and are mainly used for delivering bioactive mediators in a time-controlled or site-specific manner. Using van der Waals forces or covalent bonds, hydrophilic polymers are cross-linked and can absorb high volumes of water. Extensive studies have been conducted on nano-gels as the carriers of essential oils and pheromones [154, 155]. The potential of nano-gel systems for the delivery of AIs in a constant, targetable, and controlled manner has been proven.

Pheromones are environmentally friendly and highly specific biological control agents which require to be protected against decomposition in ambient conditions and released slowly. As evidence has revealed, the evaporation of pheromones is significantly decreased in nano-gel carriers compared with the pure AIs. This extends their efficacy up to 33 weeks compared with that of the pure AIs, which is only 3 weeks [155]. As proposed by Brunel et al., the performance of copper-based antifungal treatments can be improved using pure chitosan nano-gels [156].

The Institute of Pesticide Formulation Technology (Gurgaon) has recently presented a permethrin nano-gel formulation (a synthetic pyrethroid pesticide) for enduring the impregnation of this pesticide in clothes. This formulation protects individuals against mosquito bites while working in forest areas [157]. Another research has developed chitosan nano-capsules containing lemongrass oil in the form of gel for long-lasting anti-mosquito effects [158]. 


\section{Electrospun nano-fibers}

Electrospinning has recently emerged as useful nanotechnology for the production of nanofiber materials that can be applied in different biomedical areas [159]. Electrospinning technology can scale up and meet industrial manufacturing requirements. Recently, researchers have studied the nano-fibers generated by electrospinning for plant protection purposes. Although they are still in the early stages of agricultural application, electrospun nanofibers have the benefit of evading release bursts, resulting in the facilitation of the field application of essential oils and pheromones [160].

As reported by Hellman et al., pheromones can be efficiently incorporated into nano-fibers composed of cellulose acetate or polyamide (approximately $30 \mathrm{wt} . \%$ ), and a nearly linear release can be obtained over several weeks [161].

Xiang et al. presented an analogous nanofiber network made of cellulose and poly (lactic acid) nanocrystals. The thiamethoxam-loaded fibers were effective against whitefly over 9 days in a glasshouse experiment at $50 \%$ of the proposed dose for the pure AIs [162]. Pesticides were delivered in a localized manner by coating seeds with electrospun cellulose diacetate (CDA) nanofibers containing fluopyram or $\mathrm{Abm}$, and it was found that nanofibrous seed coating could be potentially used as an alternate approach for controlling plant pathogens, such as fungi and nematodes [163]. In another study, the authors produced the thiram/hydroxypropyl$\beta$-cyclodextrin inclusion complex nanofiber (thiram/ $\mathrm{HP} \beta \mathrm{CD}$-IC-NF) using electrospinning for efficient delivery of the pesticides [164].

\section{Future perspectives}

In a future perspective, the development of nanoparticles that can act as fertilizers and pesticides is necessary. Nanotechnology research in agriculture is still at its initial stages, but is developing quickly. The application of nanostructures as agrochemicals for plant growth and protection has to be investigated due to their novel physicochemical characteristics [165]. With clear nano-bio interactions, transport, and fate in the plant and environment, these nanoparticles have sustained release and resistance for plant protection management [166]. The majority of recently supported projects and future study calls seem to be concentrating on producing safer, environmentally friendly nanomaterials for efficient responses [165]. It is expected that the controlled release of pesticides by nanotechnologies will become essential in the near future to promote cropland fertility and protection with the least effect on the environment and human health
[166]. Future studies should be conducted using natural sources rather than standard media and assess the interaction of nano-agrochemicals with other contaminants. Soon, using nanostructured catalysts will be possible, which will enhance the effectiveness of pesticides and herbicides, allowing the use of more moderate doses. Nanotechnology will also guard the environment obliquely by promoting the use of filters or catalysts, which can decrease the contamination in soil and water [167]. Future opportunities for target delivery of crucial nutrients, pesticides, and genetic materials utilizing nanomaterials will provide new prospects for the agricultural revolution [168, 169]. However, several features of nanoparticles are supposedly dangerous to human health. Therefore, these substances must be more cautiously studied. For example, for dry nanoproducts, the relative ease with which nanopowders are suspendable in the air might lead to potential human inhalation and subsequent health hazards. On the other hand, suspensions of nanoparticles in water used as a soil drench or foliar sprays pose risks such as the transformation of the particles into ions or aggregation into submicrometer- or micrometer-sized particles [170]. Experts should evaluate the influences of nanoparticles on human health and the environment, and improve the approaches used to assess and control any hazards they may pose. Researchers also need to find renewable methods to fabricate nanoscale materials to be employed in agriculture. Moreover, general approaches should be developed in the pioneer institutes or nations to test laboratory-scale nano-products in actual farm settings for more comprehensive technology validation. Finally, educative and developmental initiatives should be established via study plans to bring the users and experts together in addressing possible customer interests.

\section{Marketed safe and target-delivered pesticides}

Since the AIs of traditional pesticides are more toxic, the demand for harmless outcomes with a safer performance propelled the development of bio- and nano-pesticides and the growth of their commercialization [171, 172]. Microbial-based pest-control products are gaining recognition and show an influential growth within the market for pest management technologies (Table 3). Despite the possible advantages of nanotechnology applications in agriculture and the increasing trend of patent applications (mainly from agrochemical companies), nano-based pesticide products have limited market reach [173]. Today, two types of nanomaterials have appeared in nano-enabled industrial pesticides accessible in the market (Table 4). 
Table 3 Several marketed microbial pesticides

\begin{tabular}{|c|c|c|}
\hline Pathogen & Marketed product & Reference \\
\hline \multicolumn{3}{|l|}{ Bacteria } \\
\hline $\begin{array}{l}\text { Bacillus thuringiensis } \\
\text { var. kurstaki (Bt) }\end{array}$ & 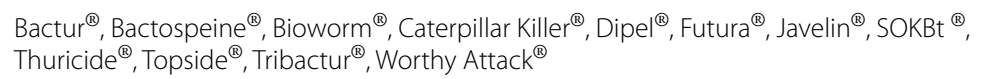 & [174] \\
\hline Bacillus thuringiensis var. israelensis (Bt) & Aquabee $^{\circledR}$, Bactimos $^{\circledR}$, Gnatrol $^{\circledR}$, LarvX $^{\circledR}$, Mosquito Attack $^{\circledR}$, Skeeta $^{\circledR}$, , Teknar $^{\circledR}$, Vectobac $^{\circledR}$ & [175] \\
\hline Bacillus thuringiensis var. tenebrinos & Foil $^{\circledR}$, M-One ${ }^{\circledR}$, M-Track $^{\circledR}$, Novardo $^{\circledR}$, Trident $^{\circledR}$ & [176] \\
\hline Bacillus thuringiensis var. aizawai & Certan $^{\circledR}$ & {$[177]$} \\
\hline $\begin{array}{l}\text { Bacillus popilliae and } \\
\text { Bacillus lentimorbus }\end{array}$ & Doom", Japidemic ${ }^{\circledR}$ Milky Spore Disease, Grub Attack ${ }^{\circledR}$ & {$[176]$} \\
\hline Bacillus sphaericus & Vectolex $\mathrm{CG}^{\circledR}$, Vectolex WDG ${ }^{\circledR}$ & {$[176]$} \\
\hline Bacillus subtilis strain 713 & Serenade ${ }^{\circledR}$ & [178] \\
\hline Bacillus pumilus strain 2808 & Sonata ${ }^{\circledR}$ & [178] \\
\hline \multicolumn{3}{|l|}{ Fungi } \\
\hline Beauveria bassiana & Botanigard $^{\circledR}$, Mycotrol $^{\circledR}$, Naturalis $^{\circledR}$ & [179] \\
\hline Lagenidium giganteum & Laginex $^{\circledR}$ & [180] \\
\hline \multicolumn{3}{|l|}{ Protozoa } \\
\hline Nosema locustae & NOLO Bait ${ }^{\circledR}$, Grasshopper Attack ${ }^{\circledR}$ & {$[175]$} \\
\hline \multicolumn{3}{|l|}{ Viruses } \\
\hline $\begin{array}{l}\text { Gypsy moth nuclear } \\
\text { plyhedrosis (NPV) }\end{array}$ & Gypchek $^{\circledR}$ virus & [181] \\
\hline Tussock moth NPV & TM Biocontrol-1 $1^{\circledR}$ & [182] \\
\hline Pine sawfly NPV & Neochek-S ${ }^{\circledR}$ & [183] \\
\hline
\end{tabular}

Table 4 Marketed nano-pesticides

\begin{tabular}{lll}
\hline Nano-pesticides & Marketed product & References \\
\hline Copper-based nano-pesticides & Kocide $^{\circledR} 3000$ (DuPont) & [184] \\
& and NANOCU & \\
Silver-based nano-pesticides & ${\text { Zeroxxee }{ }^{\circledR}, \text { Silver leaf, }}^{\text {[185] }}$ & \\
& Zeromix $^{\circledR}$ Zerebra & \\
& Agro ${ }^{\circledR}$ & \\
& WA-CV-WA13B, WA-AT- \\
& WB13R, WA-PR-WB13R \\
&
\end{tabular}

\section{Conclusion}

Population growth, the increasing need for food, and restrictions on areas under cultivation have led to pesticide overuse. As a result of climatic changes and continued global warming, the development of all possible pests on crops, fruits, vegetables, and livestock is possible. Pests are migrating to previously unexplored territories, putting farmers, and plants at risk. Therefore, synthetic pesticides are used by farmers to control these pests. However, the widespread use of pesticides causes harm to a wide variety of nonpathogenic species, and there has also been an increase in pathogens in foods, which leads to further deterioration of soil and water quality.

Nanotechnology is a relatively new method of pesticide delivery and application that is becoming increasingly relevant. The use of nanotechnology and modern nanomaterials is becoming more prevalent in agriculture and the food industry. Nano-based products have improved stability and efficiency/potency due to changed solubility and adhesion to surfaces, permeability across biological membranes, and targeted and controlled release. As a consequence of these altered properties, using lower pesticide concentrations is now possible. Moreover, biopesticides or natural-based chemicals with significant anti-pest effects are currently being manufactured. The vast majority of natural substances have drawbacks such as a short duration of action and poor stability; therefore, nanotechnological approaches have been applied, either for the development of stable biopesticide nano-formulations with long-term effects or for the "green" synthesis of active inorganic nanomaterials that are antimicrobial, antifungal, and antiparasitic.

\section{Acknowledgements \\ Not applicable.}

\section{Authors' contributions}

Conceptualization: MHN and DA; literature review and original draft reparation: DA, SF, AP, MA, and YG; writing the review and editing: MHN, GA, and DA. All authors read and approved the final manuscript.

Funding

Not applicable.

Data availability

Not applicable. 


\section{Declarations}

Ethics approval and consent to participate Not applicable.

\section{Consent for publication}

All the authors have approved the manuscript for publication.

\section{Competing interests}

The authors declare no competing interests.

\section{Author details}

1 Department of Biochemistry, Afzalipour School of Medicine, Kerman University of Medical Sciences, Kerman, Iran. ${ }^{2}$ College of Plant Protection, China Agricultural University, Beijing, China. ${ }^{3}$ Student Research Committee, Kerman University of Medical Sciences, Kerman, Iran. ${ }^{4}$ Chemical Engineering Department, Faculty of Engineering, Shahid Bahonar University of Kerman, Kerman, Iran. ${ }^{5} \mathrm{Herbal}$ and Traditional Medicines Research Center, School of Pharmacy, Kerman University of Medical Sciences, Kerman, Iran.

Received: 2 December 2021 Accepted: 16 December 2021

Published online: 15 January 2022

\section{References}

1. Cuenca JB, Tirado N, Vikström M, Lindh CH, Stenius U, Leander K, et al. Pesticide exposure among Bolivian farmers: associations between worker protection and exposure biomarkers. J Expo Sci Environ Epidemiol. 2020;30(4):730-42.

2. Abbasi-Jorjandi M, Asadikaram G, Abolhassani M, Fallah H, Abdollahdokht D, Salimi F, et al. Pesticide exposure and related health problems among family members of farmworkers in southeast Iran. A casecontrol study. Environ Pollut. 2020;267:115424.

3. Abolhassani M, Asadikaram G, Paydar P, Fallah H, Aghaee-Afshar M, Moazed $V$, et al. Organochlorine and organophosphorous pesticides may induce colorectal cancer; a case-control study. Ecotoxicol Environ Saf. 2019;178:168-77.

4. Abdollahdokht D, Asadikaram G, Abolhassani M, Pourghadamyari $\mathrm{H}_{\text {, }}$ Abbasi-Jorjandi M, Faramarz S, Nematollahi MH. Pesticide exposure and related health problems among farmworkers' children: a case-control study in southeast Iran. Environ Sci Pollut Res Int. 2021;28(40):57216-31. https://doi.org/10.1007/s11356-021-14319-1.

5. Yousefi F, Asadikaram G, Karamouzian S, Abolhassani M, Moazed V, Nematollahi MH. MGMT methylation alterations in brain cancer following organochlorine pesticides exposure. Environ Health Eng Manage. 2021;8(1):47-53. https://doi.org/10.34172/EHEM.2021.07.

6. Sun C, Cui H, Wang Y, Zeng Z, Zhao X, Cui B. Studies on applications of nanomaterial and nanotechnology in agriculture. J Agric Sci Technol. 2016:18(1):18-25.

7. Pal GK, Kumar B, Shahi S. Antifungal activity of some common weed extracts against phytopathogenic fungi Alternaria spp. Int J Univers Pharm Life Sci. 2013;3(2):6-14.

8. Mishra J, Arora NK. Bioformulations for plant growth promotion and combating phytopathogens: a sustainable approach. Bioformulations: For sustainable agriculture: Springer; 2016. p. 3-33.

9. Mason PG, Gillespie DR. Biological control programmes in Canada 2001-2012: CABI; 2013.

10. Seiber JN, Coats J, Duke SO, Gross AD. Biopesticides: state of the art and future opportunities. J Agric Food Chem. 2014;62(48):11613-9.

11. Jampílek J, Králová K. Nanobiopesticides in agriculture: State of the art and future opportunities. Nano-biopesticides today and future perspectives. 2019:397-447.

12. Huang K-S, Yang C-H, Huang S-L, Chen C-Y, Lu Y-Y, Lin Y-S. Recent advances in antimicrobial polymers: a mini-review. Int J Mol Sci. 2016;17(9):1578

13. Pentak D, Kozik V, Bąk A, Dybał P, Sochanik A, Jampilek J. Methotrexate and cytarabine - Loaded nanocarriers for multidrug cancer therapy. Spectroscopic study. Molecules. 2016;21(12):1689.
14. Vaculikova E, Cernikova A, Placha D, Pisarcik M, Dedkova K, Peikertova $P$, et al. Cimetidine nanoparticles for permeability enhancement. J Nanosci Nanotechnol. 2016;16(8):7840-3.

15. Nair R, Varghese SH, Nair BG, Maekawa T, Yoshida Y, Kumar DS. Nanoparticulate material delivery to plants. Plant Sci. 2010;179(3):154-63.

16. Clark T, Hamer M. Pesticides in perspective. Ecological risk assessmant for agricultural pesticides. J Environ Monit. 2000;2(6):104N-N105.

17. Abubakar Y, Tijjani H, Egbuna C, Adetunji CO, Kala S, Kryeziu TL, et al. Pesticides, history, and classification. Natural remedies for pest, disease and weed control. Amsterdam: Elsevier; 2020. p. 29-42.

18. Horsfall JG. Fungi and fungicides the story of a nonconformist. Ann Rev Phytopathol. 1975;13(1):1-14

19. Kelman A, Peterson PD. Contributions of plant scientists to the development of the germ theory of disease. Microbes Infect. 2002;4(2):257-60.

20. Zubrod JP, Bundschuh M, Arts G, Brühl CA, Imfeld G, Knäbel A, et al. Fungicides: an overlooked pesticide class? Environ Sci Technol. 2019;53(7):3347-65.

21. Thind T. Changing trends in discovery of new fungicides: a perspective. Indian Phytopathol. 2021:1-9.

22. Rives C, Fougerat A, Ellero-Simatos S, Loiseau N, Guillou H, GametPayrastre L, et al. Oxidative stress in NAFLD: role of nutrients and food contaminants. Biomolecules. 2020;10(12):1702.

23. Bitzenhofer J, Voegele RTJBB, Agriculture Mfl, Health $\mathrm{H}$. Challenges and Prospects of Biopesticides. 2021:281.

24. Vats S. Herbicides: history, classification and genetic manipulation of plants for herbicide resistance. Sustainable Agriculture Reviews. Berlin: Springer; 2015. p. 153-92.

25. Sany SBT, Hashim R, Salleh A, Rezayi M, Karlen DJ, Razavizadeh BB, et al. Dioxin risk assessment: mechanisms of action and possible toxicity in human health. Environ Sci Pollut Res. 2015;22(24):19434-50.

26. Zagnitko O, Jelenska J, Tevzadze G, Haselkorn R, Gornicki P. An isoleucine/leucine residue in the carboxyltransferase domain of acetyl-CoA carboxylase is critical for interaction with aryloxyphenoxypropionate and cyclohexanedione inhibitors. Proc Natl Acad Sci USA. 2001;98(12):6617-22

27. Whittingham WG. Herbicidal aryloxyphenoxypropionate inhibitors of acetyl-CoA xarboxylase. 2016:325-37.

28. Rendina AR, Felts JM. Cyclohexanedione herbicides are selective and potent inhibitors of acetyl-CoA carboxylase from grasses. Plant Physiol. 1988;86(4):983-6.

29. Takano HK, Ovejero RFL, Belchior GG, Maymone GPL, Dayan FE. ACCaseinhibiting herbicides: mechanism of action, resistance evolution and stewardship. Scientia Agricola. 2021;78:1.

30. Zhang Z, Xing A, Staswick P, Clemente TE. The use of glufosinate as a selective agent in Agrobacterium-mediated transformation of soybean. Plant Cell Tissue Organ Cul. 1999;56(1):37-46.

31. Hennens D, Benichon M, Hildebrandt J, Budd A, editors. Bixlozone: A new isoxazolidinone herbicide for a wide range of European crops. 24e Conférence du COLUMA: Journées internationales sur la lutte contre les mauvaises herbes, Orleans, France, 3, 4 et 5 décembre 2019; 2019: Végéphyl-Association pour la santé des végétaux.

32. Oberemok W, Laikova KV, Gninenko YI, Zaitsev AS, Nyadar PM, Adeyemi TA. A short history of insecticides. Plant Protect Res. 2015;55(3).

33. Abdel-Salam OM, Youness ER, Hafez HF. The antioxidant status of the plasma in patients with breast cancer undergoing chemotherapy. Physiology. 2011;1(03):29

34. Dhadialla TS, Carlson GR, Le DP. New insecticides with ecdysteroidal and juvenile hormone activity. Annu Rev Entomol. 1998:43(1):545-69.

35. Matsumura F. Studies on the action mechanism of benzoylurea insecticides to inhibit the process of chitin synthesis in insects: A review on the status of research activities in the past, the present and the future prospects. Pest Biochem Physiol. 2010;97(2):133-9.

36. Schmutterer $\mathrm{H}$. Properties and potential of natural pesticides from the neem tree, Azadirachta indica. Annu Rev Entomol. 1990;35(1):271-97.

37. Matsuda K, Buckingham SD, Kleier D, Rauh JJ, Grauso M, Sattelle DB. Neonicotinoids: insecticides acting on insect nicotinic acetylcholine receptors. Trends Pharmacol Sci. 2001;22(11):573-80.

38. Casida JE, Durkin KA. Neuroactive insecticides: targets, selectivity, resistance, and secondary effects. Annu Rev Entomol. 2013;58:99-117.

39. López Ó, Fernández-Bolaños JG, Gil MV. New trends in pest control: the search for greener insecticides. Green Chem. 2005;7(6):431-42. 
40. Pedlowski MA, Canela MC, da Costa Terra MA, de Faria RM. Modes of pesticides utilization by Brazilian smallholders and their implications for human health and the environment. Crop Protect. 2012;31(1):113-8.

41. Mostafalou S, Abdollahi M. Pesticides and human chronic diseases: evidences, mechanisms, and perspectives. Toxicol Appl Pharmacol. 2013;268(2):157-77

42. Aktar MW, Sengupta D, Chowdhury A. Impact of pesticides use in agriculture: their benefits and hazards. Interdiscip Toxicol. 2009;2(1):1.

43. Street ME, Angelini S, Bernasconi S, Burgio E, Cassio A, Catellani C, et al. Current knowledge on endocrine disrupting chemicals (EDCs) from animal biology to humans, from pregnancy to adulthood: highlights from a national Italian meeting. Int J Mol Sci. 2018;19(6):1647.

44. Sánchez-Santed F, Colomina MT, Hernández EH. Organophosphate pesticide exposure and neurodegeneration. Cortex. 2016;74:417-26.

45. Barzman M, Bàrberi P, Birch ANE, Boonekamp P, Dachbrodt-Saaydeh S, Graf B, et al. Eight principles of integrated pest management. Agron Sustain Dev. 2015;35(4):1199-215.

46. Organization WH. Exposure to highly hazardous pesticides: a major public health concern. 2010.

47. Cantrell CL, Dayan FE, Duke SO. Natural products as sources for new pesticides. J Nat Prod. 2012;75(6):1231-42.

48. Jampílek J, Králová K. Nanobiopesticides in agriculture: State of the art and future opportunities. Nano-biopesticides today and future perspectives. Amsterdam: Elsevier; 2019. p. 397-447.

49. Copping LG, Menn JJ. Biopesticides: a review of their action, applications and efficacy. Form Pest Sci. 2000;56(8):651-76

50. Harlan B, Hausbeck M, editors. Extended control of downy mildew and Phytophthora root rot on ornamentals with the novel fungicide oxathiapiprolin. International Symposium on Advanced Technologies and Management for Innovative Greenhouses: GreenSys2019 1296; 2019

51. Dara SK, Dara SS, Dara SS. First report of entomopathogenic fungi, Beauveria bassiana, Isaria fumosorosea, and Metarhizium brunneum promoting the growth and health of cabbage plants growing under water stress. UCANR eJournal Strawberries and Vegetables. 2016;19.

52. Yang $Q, M a X$, Chen $T$, Liang W. First Report of Alternaria destruens Causing Leaf Spot on Ligustrum sinense in China. Plant Dis. 2019:103(11):2959.

53. Habeeb SM, Ashry HM, Saad MM. Ovicidal effect of chitinase and protease enzymes produced by soil fungi on the camel tick Hyalomma dromedarii eggs (Acari: Ixodidae). J Parasitic Dis. 2017;41(1):268-73.

54. Abate BA, Wingfield MJ, Slippers B, Hurley BP. Commercialisation of entomopathogenic nematodes: should import regulations be revised? Biocontrol Sci Technol. 2017;27(2):149-68.

55. Vashisth S, Chandel Y, Chandel RS. Comparative efficacy of indigenous heterorhabditid nematodes from north western Himalaya and Heterorhabditis indica (Poinar, Karunakar \& David) against the larvae of Helicoverpa armigera (Hubner). Int J Pest Manag. 2019;65(1):16-22.

56. Wilson K, Grzywacz D, Curcic I, Scoates F, Harper K, Rice A, et al. A novel formulation technology for baculoviruses protects biopesticide from degradation by ultraviolet radiation. Sci Rep. 2020;10(1):1-10.

57. Julio LF, González-Coloma A, Burillo J, Diaz CE, Andrés MF. Nematicidal activity of the hydrolate byproduct from the semi industrial vapor pressure extraction of domesticated Artemisia absinthium against Meloidogyne javanica. Crop Prot. 2017:94:33-7.

58. Weeks EN, Schmehl DR, Baniszewski J, Tomé HV, Cuda JP, Ellis JD, et al. Safety of methionine, a novel biopesticide, to adult and larval honey bees (Apis mellifera L.). Ecotoxicol Environ Saf. 2018;149:211-6.

59. Powell ME, Bradish HM, Cao M, Makinson R, Brown AP, Gatehouse JA, et al. Demonstrating the potential of a novel spider venom-based biopesticide for target-specific control of the small hive beetle, a serious pest of the European honeybee. J Pest Sci. 2020:93(1):391-402.

60. Woolley VC. Elucidating the natural function of cordycepin, a secondary metabolite of the fungus Cordyceps militaris, and its potential as a novel biopesticide in Integrated Pest Management: University of Warwick; 2018.

61. Calgaro-Kozina A, Vuu KM, Keasling JD, Loqué D, Sattely ES, Shih PM. Engineering plant synthetic pathways for the biosynthesis of novel antifungals. ACS Cent Sci. 2020;6(8):1394-400.

62. Caragata EP, Otero LM, Carlson JS, Dizaji NB, Dimopoulos G. A nonlive preparation of Chromobacterium sp. Panama (Csp_P) is a highly effective larval mosquito biopesticide. Appl Environ Mictobiol. 2020;86(11):e00240.

63. Rostami A, Hinc K, Goshadrou F, Shali A, Bayat M, Hassanzadeh M, et al. Display of $B$. pumilus chitinase on the surface of $B$. subtilis spore as a potential biopesticide. Pest Biochem Physiol. 2017;140:17-23.

64. Chander S, Poddar N, Srinivasa N. Effect of insecticides including a novel molecule triflumezopyrim and biopesticides on rice planthoppers. Indian J Entomol. 2018;80(3):1220-3.

65. Alshukri BMH. Novel molecular biopesticides targeting the potassium ion channels of the red flour beetle, Tribolium castaneum (Herbst.): Newcastle University; 2018.

66. Feng J, Wang R, Chen Z, Zhang S, Yuan S, Cao H, et al. Formulation optimization of D-limonene-loaded nanoemulsions as a natural and efficient biopesticide. Colloids Surf A. 2020;596:124746.

67. Montesinos E. Development, registration and commercialization of microbial pesticides for plant protection. Int Microbiol. 2003;6(4):245-52.

68. Narayanan K. Insect defence: its impact on microbial control of insect. Curr Sci. 2004;86:800-14.

69. Dillon RJ, Dillon VM. The gut bacteria of insects: nonpathogenic interactions. Annu Rev Entomol. 2004;49(1):71-92.

70. Poopathi S, Abidha S. Mosquitocidal bacterial toxins (Bacillus sphaericus and $B$. thuringiensis serovar israelensis): mode of action, cytopathological effects and mechanism of resistance. J Physiol Pathophysiol. 2010;1(3):22-38.

71. Mao X, Yan A, Wan Y, Luo D, Yang H. Dispersive solid-phase extraction using microporous sorbent UiO-66 coupled to gas chromatographytandem mass spectrometry: a QuEChERS-Type method for the determination of organophosphorus pesticide residues in edible vegetable oils without matrix interference. J Agric Food Chem. 2019;67(6):1760-70.

72. Gupta S, Dikshit AK. Biopesticides: an ecofriendly approach for pest control. J Biopesticides. 2010;3:186.

73. Parker KM, Sander M. Environmental fate of insecticidal plant-incorporated protectants from genetically modified crops: knowledge gaps and research opportunities. ACS Publications; 2017.

74. Yang J, Sun X-Q, Zhu-Salzman K, Qin Q-M, Feng H-Q, Kong X-D, et al. Host-induced gene silencing of brown planthopper glutathione S-transferase gene enhances rice resistance to sap-sucking insect pests. J Pest Sci. 2020;94:1-13.

75. Cagliari D, Dias NP, Galdeano DM, Dos Santos EÁ, Smagghe G, Zotti MJ. Management of pest insects and plant diseases by non-transformative RNAi. Front Plant Sci. 2019:10:1319.

76. Zotti M, Dos Santos EA, Cagliari D, Christiaens O, Taning CNT, Smagghe G. RNA interference technology in crop protection against arthropod pests, pathogens and nematodes. Pest Manag Sci. 2018;74(6):1239-50.

77. Kookana RS, Boxall AB, Reeves PT, Ashauer R, Beulke S, Chaudhry Q, et al. Nanopesticides: guiding principles for regulatory evaluation of environmental risks. J Agric Food Chem. 2014;62(19):4227-40.

78. Solans C, Izquierdo P, Nolla J, Azemar N, Garcia-Celma MJ. Nano-emulsions. Curr Opin Colloid Interface Sci. 2005;10(3-4):102-10.

79. McClements DJ. Nanoemulsions versus microemulsions: terminology, differences, and similarities. Soft Matter. 2012;8(6):1719-29.

80. Singh Y, Meher JG, Raval K, Khan FA, Chaurasia M, Jain NK, et al. Nanoemulsion: concepts, development and applications in drug delivery. J Control Release. 2017;252:28-49.

81. Feng J, Zhang Q, Liu Q, Zhu Z, McClements DJ, Jafari SM. Application of Nanoemulsions in Formulation of Pesticides. Jafari SM, McClements DJ, editors2018. 379-413 p

82. Wang L, Li X, Zhang G, Dong J, Eastoe J. Oil-in-water nanoemulsions for pesticide formulations. J Colloid Interface Sci. 2007;314(1):230-5.

83. Liu Y, Wei F, Wang Y, Zhu G. Studies on the formation of bifenthrin oil-inwater nano-emulsions prepared with mixed surfactants. Colloids Surf A 2011;389(1-3):90-6.

84. Pavoni L, Pavela R, Cespi M, Bonacucina G, Maggi F, Zeni V, et al. Green micro- and nanoemulsions for managing parasites, vectors and pests. Nanomaterials. 2019;9(9):1285.

85. Jiang LC, Basri M, Omar D, Rahman MBA, Salleh AB, Rahman RN, et al. Green nano-emulsion intervention for water-soluble glyphosate isopropylamine (IPA) formulations in controlling Eleusine indica (E. indica). Pesticide Biochem Physiol. 2012;102(1):19-29. 
86. Feng J, Chen W, Liu Q, Chen Z, Yang J, Yang W. Development of abamectin-loaded nanoemulsion and its insecticidal activity and cytotoxicity. Pest Manag Sci. 2020;76(12):4192-201.

87. Castro MJL, Ojeda C, Fernandez CA. Advances in surfactants for agrochemicals. Environ Chem Lett. 2014;12(1):85-95.

88. McClements DJ. Edible nanoemulsions: fabrication, properties, and functional performance. Soft Matter. 2011;7(6):2297-316.

89. Ci J, Cao C, Kuga S, Shen J, Wu M, Huang Y. Improved performance of microbial fuel cell using esterified corncob cellulose nanofibers to fabricate air-cathode gas diffusion layer. Acs Sustain Chem Eng. 2017;5(11):9614-8.

90. Wang L, Dong J, Chen J, Eastoe J, Li X. Design and optimization of a new self-nanoemulsifying drug delivery system. J Colloid Interface Sci. 2009;330(2):443-8.

91. Nuruzzaman M, Rahman MM, Liu Y, Naidu R. Nanoencapsulation, nano-guard for pesticides: a new window for safe application. J Agric Food Chem. 2016;64(7):1447-83.

92. Vurro M, Miquel-Rojas C, Perez-de-Luque A. Safe nanotechnologies for increasing the effectiveness of environmentally friendly natural agrochemicals. Pest Manag Sci. 2019;75(9):2403-12.

93. Zhao X, Cui H, Wang Y, Sun C, Cui B, Zeng Z. Development strategies and prospects of nano-based smart pesticide formulation. J Agric Food Chem. 2018;66(26):6504-12.

94. Camara MC, Ramos Campos EV, Monteiro RA, Santo Pereira AE, de Freitas Proenca PL, Fraceto LF. Development of stimuli-responsive nano-based pesticides: emerging opportunities for agriculture. J Nanobiotechnol. 2019;17(1):100.

95. Kumar S, Nehra M, Dilbaghi N, Marrazza G, Hassan AA, Kim K-H. Nanobased smart pesticide formulations: emerging opportunities for agriculture. J Control Release. 2019;294:131-53.

96. Mattos BD, Tardy BL, Magalhaes WLE, Rojas OJ. Controlled release for crop and wood protection: recent progress toward sustainable and safe nanostructured biocidal systems. J Control Release. 2017;262:139-50.

97. Arasoglu T, Mansuroglu B, Derman S, Gumus B, Kocyigit B, Acar T, et al. Enhancement of antifungal activity of juglone (5-Hydroxy1,4-naphthoquinone) using a poly(D, L-lactic-co-glycolic acid) (PLGA) nanoparticle system. J Agric Food Chem. 2016;64(38):7087-94.

98. Liang W, Yu A, Wang G, Zheng F, Hu P, Jia J, et al. A novel water-based chitosan-La pesticide nanocarrier enhancing defense responses in rice (Oryza sativa L.) growth. Carbohydr Polym. 2018;199:437-44.

99. Pang L, Gao Z, Feng H, Wang S, Wang Q. Cellulose based materials for controlled release formulations of agrochemicals: a review of modifications and applications. J Control Release. 2019;316:105-15.

100. Shakiba S, Astete CE, Paudel S, Sabliov CM, Rodrigues DF, Louie SM. Emerging investigator series: polymeric nanocarriers for agricultural applications: synthesis, characterization, and environmental and biological interactions. Environ Sci Nano. 2020;7(1):37-67.

101. Tong Y, Wu Y, Zhao C, Xu Y, Lu J, Xiang S, et al. Polymeric nanoparticles as a metolachlor carrier: water-based formulation for hydrophobic pesticides and absorption by plants. J Agric Food Chem. 2017;65(34):7371-8.

102. Yan S, Hu Q, Li J, Chao Z, Cai C, Yin M, et al. A star polycation acts as a drug nanocarrier to improve the toxicity and persistence of botanical pesticides. Acs Sustain Chem Eng. 2019;7(20):17406-13.

103. de Oliveira JL, Ramos Campos EV, Goncalves da Silva CM, Pasquoto T, Lima R, Fraceto LF. Solid lipid nanoparticles co-loaded with simazine and atrazine: preparation, characterization, and evaluation of herbicidal activity. J Agric Food Chem. 2015;63(2):422-32.

104. Hiep Minh N, Hwang I-C, Park J-W, Park H-J. Photoprotection for deltamethrin using chitosan-coated beeswax solid lipid nanoparticles. Pest Manag Sci. 2012;68(7):1062-8.

105. Cao J, Guenther RH, Sit TL, Lommel SA, Opperman CH, Willoughby JA Development of abamectin loaded plant virus nanoparticles for efficacious plant parasitic nematode control. ACS Appl Mater Interfaces. 2015;7(18):9546-53.

106. Chariou PL, Dogan AB, Welsh AG, Saidel GM, Baskaran H, Steinmetz NF. Soil mobility of synthetic and virus-based model nanopesticides. Nat Nanotechnol. 2019;14(7):712.
107. Chariou PL, Steinmetz NF. Delivery of pesticides to plant parasitic nematodes using tobacco mild green mosaic virus as a nanocarrier. ACS Nano. 2017:11(5):4719-30.

108. Chen C, Zhang G, Dai Z, Xiang Y, Liu B, Bian P, et al. Fabrication of light-responsively controlled-release herbicide using a nanocomposite. Chem Eng J. 2018;349:101-10.

109. Gijsman P. Review on the thermo-oxidative degradation of polymers during processing and in service. e-Polymers. 2008;8(1).

110. Cai A-Y, Zhu Y-J, Qi C. Biodegradable Inorganic Nanostructured Biomaterials for Drug Delivery. Adv Mater Interfaces. 2020;7:2000819.

111. Cao L, Zhang H, Zhou Z, Xu C, Shan Y, Lin Y, et al. Fluorophore-free luminescent double-shelled hollow mesoporous silica nanoparticles as pesticide delivery vehicles. Nanoscale. 2018;10(43):20354-65.

112. Chen H, Lin Y, Zhou H, Zhou X, Gong S, Xu H. Synthesis and characterization of chlorpyrifos/Copper(II) Schiff Base Mesoporous Silica with $\mathrm{pH}$ sensitivity for pesticide sustained release. J Agric Food Chem. 2016;64(43):8095-102.

113. Gao Y, Kaziem AE, Zhang Y, Xiao Y, He S, Li J. A hollow mesoporous silica and poly(diacetone acrylamide) composite with sustained-release and adhesion properties. Microporous Mesoporous Mater. 2018;255:15-22.

114. Gao Y, Liang Y, Dong H, Niu J, Tang J, Yang J, et al. A bioresponsive system based on mesoporous organosilica nanoparticles for smart delivery of fungicide in response to pathogen presence. Acs Sustain Chem Eng. 2020;8(14):5716-23.

115. Li ZZ, Xu SA, Wen LX, Liu F, Liu AQ, Wang Q, et al. Controlled release of avermectin from porous hollow silica nanoparticles: influence of shell thickness on loading efficiency, UV-shielding property and release. J Control Release. 2006;111(1-2):81-8.

116. Qian K, Shi T, Tang T, Zhang S, Liu X, Cao Y. Preparation and characterization of nano-sized calcium carbonate as controlled release pesticide carrier for validamycin against Rhizoctonia solani. Microchim Acta. 2011;173(1-2):51-7

117. Nuruzzaman M, Ren J, Liu Y, Rahman MM, Shon HK, Naidu R. Hollow porous silica nanosphere with single large pore opening for pesticide loading and delivery. Acs Appli Nano Mater. 2020;3(1):105-13.

118. Popat A, Liu J, Hu Q, Kennedy M, Peters B, Lu GQ, et al. Adsorption and release of biocides with mesoporous silica nanoparticles. Nanoscale. 2012:4(3):970-5.

119. Xiang Y, Wang N, Song J, Cai D, Wu Z. Micro-nanopores fabricated by high-energy electron beam irradiation: suitable structure for controlling pesticide loss. J Agric Food Chem. 2013;61(22):5215-9.

120. Sharma S, Singh S, Ganguli AK, Shanmugam V. Anti-drift nano-stickers made of graphene oxide for targeted pesticide delivery and crop pest control. Carbon. 2017;115:781-90.

121. Gao C, Huang Q, Lan Q, Feng Y, Tang F, Hoi MPM, et al. A user-friendly herbicide derived from photo-responsive supramolecular vesicles. Nat Commun. 2018:9:2967.

122. Gao Y, Xiao Y, Mao K, Qin X, Zhang Y, Li D, et al. Thermoresponsive polymer-encapsulated hollow mesoporous silica nanoparticles and their application in insecticide delivery. Chem Eng J. 2020;383:123169.

123. Huang B, Chen F, Shen Y, Qian K, Wang Y, Sun C, et al. Advances in targeted pesticides with environmentally responsive controlled release by nanotechnology. Nanomaterials. 2018;8(2):102.

124. Liang Y, Gao Y, Wang W, Dong H, Tang R, Yang J, et al. Fabrication of smart stimuli-responsive mesoporous organosilica nano-vehicles for targeted pesticide delivery. J Hazard Mater. 2020;389:122075.

125. Lowry GV, Avellan A, Gilbertson LM. Opportunities and challenges for nanotechnology in the agri-tech revolution. Nat Nanotechnol. 2019;14(6):517-22.

126. Tang J, Ding G, Niu J, Zhang W, Tang G, Liang Y, et al. Preparation and characterization of tebuconazole metal-organic frameworkbased microcapsules with dual-microbicidal activity. Chem Eng J. 2019;359:225-32.

127. Nematollahi MH, Pardakhty A, Torkzadeh-Mahanai M, Mehrabani M Asadikaram G. Changes in physical and chemical properties of niosome membrane induced by cholesterol: a promising approach for niosome bilayer intervention. RSC Adv. 2017;7(78):49463-72

128. Ross C, Taylor M, Fullwood N, Allsop D. Liposome delivery systems for the treatment of Alzheimer's disease. Int J Nanomed. 2018;13:8507.

129. Kang MA, Seo MJ, Hwang IC, Jang C, Park HJ, Yu YM, et al. Insecticidal activity and feeding behavior of the green peach aphid, Myzus 
persicae, after treatment with nano types of pyrifluquinazon. J Asia Pac Entomol. 2012;15(4):533-41.

130. Gao C, Huang Q, Lan Q, Feng Y, Tang F, Hoi MP, et al. A user-friendly herbicide derived from photo-responsive supramolecular vesicles. Nat Commun. 2018;9(1):1-13.

131. Zhang Y, Cui J, Zhou Y, Cao J, Gong H, Zhang H, et al. Liposome mediated double-stranded RNA delivery to silence ribosomal protein PO in the tick Rhipicephalus haemaphysaloides. Ticks Tick-Borne Dis. 2018;9(3):638-44.

132. Castellanos NL, Smagghe G, Sharma R, Oliveira EE, Christiaens O. Liposome encapsulation and EDTA formulation of dsRNA targeting essential genes increase oral RNAi-caused mortality in the Neotropical stink bug Euschistus heros. Pest Manag Sci. 2019;75(2):537-48

133. Parsons KH, Mondal MH, McCormick CL, Flynt AS. Guanidinium-functionalized interpolyelectrolyte complexes enabling RNAi in resistant insect pests. Biomacromol. 2018;19(4):1111-7.

134. Huang J-H, Liu Y, Lin Y-H, Belles X, Lee H-J. Practical use of RNA interference: oral delivery of double-stranded RNA in liposome carriers for cockroaches. J Vis Exp. 2018;135:e57385.

135. Taning CNT, Christiaens O, Berkvens N, Casteels H, Maes M, Smagghe G. Oral RNAi to control Drosophila suzukii: laboratory testing against larval and adult stages. J Pest Sci. 2016;89(3):803-14.

136. Whyard S, Singh AD, Wong S. Ingested double-stranded RNAs can act as species-specific insecticides. Insect Biochem Mol Biol. 2009;39(11):824-32

137. Theerawanitchpan G, Saengkrit N, Sajomsang W, Gonil P, Ruktanonchai U, Saesoo S, et al. Chitosan and its quaternized derivative as effective long dsRNA carriers targeting shrimp virus in Spodoptera frugiperda 9 cells. J Biotechnol. 2012;160(3-4):97-104.

138. Bedoya-Pérez LP, Cancino-Rodezno A, Flores-Escobar B, Soberón M, Bravo A. Role of UPR pathway in defense response of Aedes aegypti against Cry11Aa toxin from Bacillus thuringiensis. Int J Mol Sci. 2013;14(4):8467-78.

139. Cancino-Rodezno A, Alexander C, Villaseñor R, Pacheco S, Porta H, Pauchet $Y$, et al. The mitogen-activated protein kinase p38 is involved in insect defense against Cry toxins from Bacillus thuringiensis. Insect Biochem Mol Biol. 2010;40(1):58-63.

140. Pestovsky YS, Martinez-Antonio A. The use of nanoparticles and nanoformulations in agriculture. J Nanosci Nanotechnol. 2017;17(12):8699-730.

141. Debnath N, Das S, Seth D, Chandra R, Bhattacharya SC, Goswami A. Entomotoxic effect of silica nanoparticles against Sitophilus oryzae (L.). J Pest Sci. 2011;84(1):99-105.

142. Marimuthu S, Rahumani AA, Jayaseelan C, Kirthi AV, Santhoshkumar T, Velayutham K, et al. Acaricidal activity of synthesized titanium dioxide nanoparticles using Calotropis gigantea against Rhipicephalus microplus and Haemaphysalis bispinosa. Asian Pac J Trop Med. 2013;6(9):682-8.

143. Rajakumar G, Rahuman AA, Velayutham K, Ramyadevi J, Jeyasubramanian K, Marikani A, et al. Novel and simple approach using synthesized nickel nanoparticles to control blood-sucking parasites. Vet Parasitol. 2013;191(3-4):332-9.

144. Elmer W, White JC. The Future of Nanotechnology in Plant Pathology. In: Leach JE, Lindow SE, editors. Annual Review of Phytopathology, Vol 56. Annual Review of Phytopathology. 562018. p. 111-33.

145. Garg D, Sarkar A, Chand P, Bansal P, Gola D, Sharma S, et al. Synthesis of silver nanoparticles utilizing various biological systems: mechanisms and applications-a review. Prog Biomater. 2020;9(3):81-95.

146. Smitha SL, Gopchandran KG. Surface enhanced Raman scattering antibacterial and antifungal active triangular gold nanoparticles. Spectrochimica Acta Part A. 2013;102:114-9.

147. Choudhury SR, Ghosh M, Goswami A. Inhibitory effects of sulfur nanoparticles on membrane lipids of Aspergillus niger: a novel route of fungistasis. Curr Microbiol. 2012;65(1):91-7.

148. Fu L-H, Hu K-D, Hu L-Y, Li Y-H, Hu L-B, Yan H, et al. An Antifungal role of hydrogen sulfide on the postharvest pathogens Aspergillus niger and Penicillium italicum. PLoS ONE. 2014;9(8):e104206.

149. Chen J, Wang $X$, Han H. A new function of graphene oxide emerges: inactivating phytopathogenic bacterium Xanthomonas oryzae pv. Oryzae. J Nanoparticle Res. 2013;15(5):1-4.
150. Saharan V, Mehrotra A, Khatik R, Rawal P, Sharma SS, Pal A. Synthesis of chitosan based nanoparticles and their in vitro evaluation against phytopathogenic fungi. Int J Biol Macromol. 2013;62:677-83.

151. Xing K, Shen X, Zhu X, Ju X, Miao X, Tian J, et al. Synthesis and in vitro antifungal efficacy of oleoyl-chitosan nanoparticles against plant pathogenic fungi. Int J Biol Macromol. 2016;82:830-6.

152. Cui B, Lv Y, Gao F, Wang C, Zeng Z, Wang Y, et al. Improving abamectin bioavailability via nanosuspension constructed by wet milling technique. Pest Manag Sci. 2019;75(10):2756-64.

153. Wang C, Guo L, Yao J, Wang A, Gao F, Zhao X, et al. Preparation, characterization and antifungal activity of pyraclostrobin solid nanodispersion by self-emulsifying technique. Pest Manag Sci. 2019;75(10):2785-93.

154. Abreu FO, Oliveira EF, Paula HC, de Paula RC. Chitosan/cashew gum nanogels for essential oil encapsulation. Carbohyd Polym. 2012;89(4):1277-82

155. Bhagat D, Samanta SK, Bhattacharya S. Efficient management of fruit pests by pheromone nanogels. Sci Rep. 2013;3(1):1-8.

156. Brunel F, El Gueddari NE, Moerschbacher BM. Complexation of copper (II) with chitosan nanogels: toward control of microbial growth. Carbohyd Polym. 2013;92(2):1348-56

157. Mourey TH, Leon JW, Bennett JR, Bryan TG, Slater LA, Balke ST. Characterizing property distributions of polymeric nanogels by size-exclusion chromatography. J Chromatogr A. 2007;1146(1):51-60.

158. Kala S, Agarwal A, Sogan N, Naik S, Nagpal B, Patanjali P, et al. Chitosanacrylate nanogel for durable anti mosquito finishing of cotton fabric and its dermal toxicity profiling on Swiss albino mice. Colloids Surf, B. 2019;181:789-97.

159. Chen S, John JV, McCarthy A, Xie J. New forms of electrospun nanofiber materials for biomedical applications. J Mater Chem B. 2020;8(17):3733-46.

160. Sun C, Zeng Z, Cui H, Verheggen F. Polymer-Based Nanoinsecticides: Current Developments, Environmental Risks and Future ChallengesA Review. Biotechnologie, Agronomie, Société et Environnement. 2020;24.

161. Hellmann C, Greiner A, Wendorff JH. Design of pheromone releasing nanofibers for plant protection. Polym Adv Technol. 2011;22(4):407-13.

162. Xiang C, Taylor AG, Hinestroza JP, Frey MW. Controlled release of nonionic compounds from poly (lactic acid)/cellulose nanocrystal nanocomposite fibers. J Appl Polym Sci. 2013;127(1):79-86.

163. Farias BV, Pirzada T, Mathew R, Sit TL, Opperman C, Khan SA. Electrospun polymer nanofibers as seed coatings for crop protection. ACS Sustain Chem Eng. 2019:7(24):19848-56.

164. Gao S, Liu Y, Jiang J, Li X, Ye F, Fu Y, et al. Thiram/hydroxypropyl$\beta$-cyclodextrin inclusion complex electrospun nanofibers for a fast dissolving water-based drug delivery system. Colloids Surf B. 2021:201:111625

165. Raliya R, Saharan V, Dimkpa C, Biswas P. Nanofertilizer for precision and sustainable agriculture: current state and future perspectives. J Agric Food Chem. 2017:66(26):6487-503.

166. Fraceto LF, de Castro VLS, Grillo R, Ávila D, Oliveira HC, Lima R. Nanopesticides: from research and development to mechanisms of action and sustainable use in agriculture. Berlin: Springer; 2020.

167. Prasad R, Kumar V, Prasad KS. Nanotechnology in sustainable agriculture: present concerns and future aspects. Afr J Biotech. 2014:13(6):705-13.

168. Wang P, Lombi E, Zhao F-J, Kopittke PM. Nanotechnology: a new opportunity in plant sciences. Trends Plant Sci. 2016;21(8):699-712.

169. Monreal C, DeRosa M, Mallubhotla S, Bindraban P, Dimkpa C. Nanotechnologies for increasing the crop use efficiency of fertilizer-micronutrients. Biol Fertil Soils. 2016;52(3):423-37.

170. Dimkpa CO, Bindraban PS. Nanofertilizers: new products for the industry? J Agric Food Chem. 2017;66(26):6462-73.

171. Marrone PG. The market and potential for biopesticides. Biopesticides: state of the art and future opportunities. Washington: ACS Publications; 2014. p. 245-58.

172. Hack B, Egger H, Uhlemann J, Henriet M, Wirth W, Vermeer AW, et al. Advanced agrochemical formulations through encapsulation strategies? Chem Ing Tec. 2012;84(3):223-34.

173. Parisi C, Vigani M, Rodríguez-Cerezo E. Agricultural nanotechnologies: what are the current possibilities? Nano Today. 2015;10(2):124-7. 
174. Juárez LAM, Gutiérrez CG. Modelo Tecnológico Industrial para la producción de Bioinsecticidas. Revista Multidisciplinaria de Avances de Investigación. 2019;5(2):1-11.

175. Inci A, Kilic E, Canhilal R. Entomopathogens in control of urban pests. 2014.

176. Chakoosari MMD. Efficacy of various biological and microbial insecticides. J Biol Today's World. 2013;2(5):249-54.

177. Prasad A, Kumar D, Srivastava M, Sharma E, Mathur P. Soil bacteria and their possible role in mosquito control: a short review. World J Environ Biosci. 2012;2(1):40-8.

178. Cordova-Kreylos AL, Fernandez LE, Koivunen M, Yang A, Flor-Weiler L, Marrone PG. Isolation and characterization of Burkholderia rinojensis sp. nov, a non-Burkholderia cepacia complex soil bacterium with insecticidal and miticidal activities. Appl Environ Microbiol. 2013;79(24):7669-78.

179. Castrillo L, Griggs M, Vandenberg J. Vegetative compatibility groups in indigenous and mass-released strains of the entomopathogenic fungus Beauveria bassiana: likelihood of recombination in the field. J Invertebr Pathol. 2004;86(1-2):26-37.

180. Hallom C, Schreiber E, Vo T, Bloomquist M. Field trials of three concentrations of LaginexTM as Biological Larvicide compared to VectobacTM$12 \mathrm{AS}$ as a biocontrol agent for Culex quinquefasciatus. J Am Mosq Control Assoc. 2000;16:5-8.

181. Podgwaite JD. Gypchek: biological insecticide for the gypsy moth. J Forest. 1999;97(3):16-9.

182. Arthurs S, Dara SK. Microbial biopesticides for invertebrate pests and their markets in the United States. J Invertebr Pathol. 2019;165:13-21.

183. Podgwaite JD, Rush P, Hall D, Walton GS. Efficacy of the Neodiprion sertifer (Hymenoptera: Diprionidae) nucleopolyhedrosis virus (Baculovirus) product, Neochek-S. J Econ Entomol. 1984;77(2):525-8.

184. Li J, Rodrigues S, Tsyusko OV, Unrine JM. Comparing plant-insect trophic transfer of $\mathrm{Cu}$ from lab-synthesised nano- $\mathrm{Cu}(\mathrm{OH}) 2$ with a commercial nano- $\mathrm{Cu}(\mathrm{OH}) 2$ fungicide formulation. Environ Chem. 2019;16(6):411-8.

185. Jung J-H, Kim S-W, Min J-S, Kim Y-J, Lamsal K, Kim KS, et al. The effect of nano-silver liquid against the white rot of the green onion caused by Sclerotium cepivorum. Mycobiology. 2010;38(1):39-45.

\section{Publisher's Note}

Springer Nature remains neutral with regard to jurisdictional claims in published maps and institutional affiliations.

\section{Submit your manuscript to a SpringerOpen ${ }^{\circ}$ journal and benefit from:}

- Convenient online submission

- Rigorous peer review

- Open access: articles freely available online

- High visibility within the field

- Retaining the copyright to your article

Submit your next manuscript at $\gg$ springeropen.com 